\title{
ABSTRACTS
}

This section of the ANNALS is published in collaboration with the two abstracting Journals, Abstracts of World Medicine and Ophthalmic Literature, published by the British Medical Association.

The abstracts selected for this Journal are divided into the following sections:

Acute Rheumatism
Rheumatoid Arthritis
Still's Disease
Osteo-Arthritis
Spondylitis
Inflammatory Arthritides
Gout
Bone Diseases

Non-articular Rheumatism, including Disk

Syndromes, Sciatica, etc.

Pararheumatic (Collagen) Diseases

Connective Tissue Studies

Immunology and Serology

Biochemical Studies

Therapy

Other General Subjects

At the end of each section is a list of titles of articles noted but not abstracted.

Not all sections may be represented in any one issue.

Acute Rheumatism

Current Evaluation of the Diagnosis, Treatment, and Prevention of Rheumatic Fever. (Valoración corriente del diagnóstico, tratamiento y prevención de la fiebre reumática.) Stollerman, G. M. (1964). Arch. argent. Reum., 27, 98.18 refs.

Prophylaxis of Rheumatic Fever, Technique and Fundamental Principles. (Profilaxia da doença reumática. Técnica e princípios fundamentais.) DÉCURT, L. V. (1963). Rev. Ass. med. bras., 9, 259.

Prophylaxis of Rheumatic Fever and Rheumatic Heart Disease: Technical Aspects and Social Value. (La profiliasi del reumatismo articolare acuto e della cardiopatia reumatica: aspetti tecnici e suo valore sociale.) GuISEPPE, F. DI (1963). Reumatismo, 15, 434. 49 refs.

The School in the Campaign against Rheumatic Fever. (La scuola nella lotta contro la malattia reumatica.) GotTI, D., and Gobesson, D. (1963). Clin. pediat. (Bologna), 45, 561.10 refs.

Early Diagnosis of Rheumatic Carditis in Children. (Comentarios al diagnóstico precoz de la carditis reumática del niño.) SÁNCHeZ-Puelles, M. (1964). Acta pediát. esp., 22, 24.

Current Aspects of Rheumatic Fever. (Aspectos atuais da febre reumática a natureza do processo reumático.) De Mello Filho, J., and ANGelo PaPi, J. (1964). J. bras. Med., 8, 32. 10 figs, 77 refs.

Rheumatic Chorea; Clinical Features and Diagnosis. (Corea reumática: Clínica y diagnóstico.) SÁNCHEZ Villares, E. (1964). Acta pediát. esp., 22, 131. 2 figs.
Aetiological Therapy of Rheumatic Carditis. (La terapia eziologica della cardite reumatica.) Condorelli, $\mathbf{L}$. (1964). Rif. med., 78, 421.33 figs.

Treatment of Rheumatic Fever in Hospitals and Sanatoria. (Le traitement du rhumatisme articulaire aigu d'après une experience hospitalière et sanatoriale.) AUDIER, M. (1964). Arch. Méd. gén. trop., 41,97.

Effect of Corticotherapy in High Dosage on the Prevention of Rheumatic Carditis and its Sequelae. Report of $\mathbf{4 0}$ Cases. (Effet de la corticothérapie à dose forte sur la prévention des cardites rhumatismales et de leurs séquelles. Bilan 40 malades.) MAIRE, J., LÉVÊQUE, B., Corone, P., Debauchez, C., and Nizard, J. (1964). Ann. Pédiat., 40, 1287. 4 refs.

Age Peculiarities of Rheumatic Fever in Children. ShVAReVA, A. I. (1963). J. Indian pediat. Soc., 2, 391.

Evaluation of Electrocardiographic Changes in Rheumatic Carditis. (Sulla valutazione delle alterazioni elettrocardiografiche nelle cardite reumatica.) MARINO, M., D'Onofrio, V., and Rossoni, C. (1963). Aggiorn. pediat., 14, 543 . 3 figs, bibl.

Valvular Lesions following Rheumatic Fever. Treatment, Indications, and Results. (Séquelles valvulaires de la maladie de Bouillaud. Traitement, indications, et résultats.) Michaud, P., and Viard, H. (1964). Rhumatologie, 16, 61

Reactivity of the Organism in the Pathogenesis of Rheumatic Fever. (La réactivité de l'organisme dans la pathogénie du rhumatisme articulaire aigu.) REJHOLEC, V. (1964). Rhumatologie, 16, 51. 3 figs. 
Behaviour of Skin Reactions to Streptolysin with Consideration of the Antistreptolysin-0 Level in Rheumatic Fever in Children. (Zachowanie sie odczynów skórnych na streptolizyne $\mathrm{z}$ uwzglednienien poziomu antystreptolizyn o w przebiegu choroby reumatycznej u dzieci.) Ganczarski, A., Brózik, H., and Mikucki, J. (1964). Pediat. pol., 39, 17.10 refs.

Immunology and Rheumatic Fever. (Immunologie et rhumatisme articulaire aigu.) REJHOLEC, V. (1964). Rhumatologie, 14, 57.

Antistreptococcal Antibodies in Rheumatic Fever. (Gli anticorpi antistreptococcici nel reumatismo articolare acuto.) Pianigiani, A., and Pianigiani, M. (1963). Ann. Sclavo, 5, 838. 4 figs, 55 refs.

Critical Evaluation of the Determination of the Serum Sialic Acid Content in the Diagnosis and Assessment of the Activity of Rheumatic Fever. (Kritické zhodnotenie stanovenia sialovej kyseliny pre diagnostiku a posúdenie aktivity reumatickej horúčky.) SıŤaJ, S., MARkovič, O., and VLK, I. (1964). Čas. Lěk. čes., 103, 509. 28 refs.

\section{Rheumatoid Arthritis}

Rheumatoid Arthritis and Pemphigoid. LillicraP, D. A., (1963). Proc. roy. Soc. Med., 56, 921. 1 fig., 2 refs.

Bullous pemphigoid describes an eruption of uncertain aetiology characterized by subepidermal blisters and sometimes erythema multiforme-like lesions. It has been reported in association with carcinoma but not hitherto with rheumatoid arthritis.

A man aged 56 had had rheumatoid arthritis for 12 years and irritation in the axillae and groins for 3 years; 2 months previously the irritation had spread to most of the body and was accompanied by profound toxaemia and a bullous eruption, clinically and histologically characteristic of pemphigoid. Details of treatment previous to the onset of the eruption are not recorded. Clubbing of the fingers was noted in addition to changes typical of rheumatoid arthritis in the hands. Laboratory investigations included $\mathrm{Hb} 50$ per cent.; erythrocyte sedimentation rate $4 \mathrm{~mm}$./ $1 \mathrm{hr}$ (Westergren); white blood cells 44,000 (neutrophils 23,400, eosinophils 17,300). Serum proteins $4 \cdot 2$, albumin $1 \cdot 2$, globulin $3 \mathrm{~g} . / 100 \mathrm{ml}$. Latex test positive. Serum electrolytes normal at first but hypokalaemia seen later. Chest $x$ ray showed reticulate shadowing throughout the lung fields, particularly in the lower zones. Muscle biopsy normal.

No relief was obtained with sulphapyridine and Dapsone over a period of 3 days, and steroid treatment was begun. The blisters ceased with a dosage of prednisone $60 \mathrm{mg}$. and ACTH $80 \mathrm{mg}$. daily. Over a period of 4 months the dosage was reduced to $20 \mathrm{mg}$ prednisone daily and ACTH $20 \mathrm{mg}$. twice weekly, without recurrence of the eruption. The eosinophilia and leucocytosis settled and a chest $x$ ray showed marked reduction in the reticulate shadowing.

The authors consider that the joint changes, fingerclubbing, and chest $x$ ray suggest a systemic rheumatoid disease with satisfactory response to steroids, and that these findings, together with the intense eosinophilia, suggest a direct relationship between the bullous pemphigoid and the systemic rheumatoid disease, although a chance association cannot be excluded.

\section{H.J. Wallace}

Rheumatoid Arthritis; Prevalence in a Tropical Area. Méndez-Bryan, R., GonZÁlez-Alcover, R., and ROGER, L. (1964). Arthr. and Rheum., 7, 171. 1 fig., 15 refs.

Epidemiology of Rheumatoid Arthritis in Israel; Methodological Considerations. Abramson, J. H., AKLer, E., Ben Hader, S., Elkan, Z., Gabriel, K. R., and WAHL, M. (1964). Arthr. and Rheum., 7, 153. 27 refs.

Rheumatoid Heart Disease. Schoene, R. H., and RisSe, G. B. (1964). Ohio St. med.J., 60, 377. 4 figs, 20 refs.

Electrocardiogram and Dysproteinemia in Rheumatoid Arthritis. Katuyasu, A. (1964). Geriatrics, 19, 271. 15 refs.

Capillary Structure and Function in Rheumatoid Arthritis. BRÅNEMARK, P. I., LindSTrom, J., JonsSON, I., LAINE, V., and VAINIO, K. (1963). Acta rheum. scand., 9, 284. 7 figs, 6 refs.

Principles of Anesthetic Management in Rheumatoid Arthritic Patients. Edelist, G. (1964). Anesth. Analg. curr. Res., 43, 227. 30 refs.

Septic Complications in Rheumatoid Arthritis. GaULHOFER, DE WLERCK, E. H., and VAN DAM, G. (1963). Acta rheum. scand., 9, 254. 1 fig., 9 refs.

Roentgenological Study of Asymmetry in Rheumatoid Arthritis. SollA, P. (1963). Acta rheum. scand., 9, 264. 4 refs.

Surgical Management of the Arthritic with Peptic Ulceration. Payne, J. T. (1964). West. J. Surg., 72, 57. 3 refs.

Surgery of Rheumatoid Arthritis of the Knee Joint. MORI, M. (1964). Rheumatism, 20, 35. 4 figs, 23 refs.

Rupture of the Extensor Tendons of the Wrist in Rheumatoid Arthritis. (Ruptura de los tendones extensores de la muñeca en la artritis reumatoidea.) Velayos Loli, E., and CARuso, A. C. (1963). Arch. argent. Reum., 27, 65.10 refs.

Chronic Rheumatoid Polyarthritis in Cases of Silicosis. (Les polyarthrite chroniques rhumatismales des silicotiques.) Rampon, S., and Plagne, M. R. (1964). Rhumatologie, 16, 67. Bibl. 
Rheumatoid Arthritis and Chronic Lymphoid Leucosis. (Polyarthrite rhumatoïde et leucose lymphoide chronique.) KAHN, M. F., RYCKEWAERT, A., and Welfling, J. (1963). Rev. Rhum., 30, 801.

\section{Still's Disease}

Chronic Rheumatism in Infancy; Still's Disease and Ankylosing and Deforming Chronic Polyarthritis. (Reumatismo cronico dell'infanzia: malattia di Still e poliartrite cronica anchilosante e deformante.) BIANCHEDI S., Giordano, S., and Villa Venzano, G. (1964). Minerva pediat., 16, 435 . 19 figs, bibl.

\section{Osteo-Arthritis}

Protrusio acetabuli. II. Osteo-arthritic Complications. (La malformation protrusive et sa complication arthrosique. II. Ruelle, M., and Dubois, J. L. (1962). Rev. Rhum., 29, 646.7 figs, 49 refs.

The authors discuss the clinical and radiological features of the condition of "protrusio acetabuli". They aduce reasons for considering it to be not a true primary coxopathy sui generis, but an acquired pelvicoxofemoral malformation developed in reaction to the initial luxating condition. The condition is frequently bilateral and predominantly affects female patients of advancing years. The ultimate pathogenesis remains obscure, a pelvi-femoral malformation of genetic origin could be responsible for a certain degree of chondrodysplasia, which in turn might cause depression of the floor of the acetabulum and initiate the condition. Osteo-arthritis may occur as a complication of protrusio acetabuli and the authors discuss the features whereby it may be distinguished clinically and radiologically from other types of osteo-arthritis.

W. R. Menke

Generalized Primary Osteo-arthritis and its Treatment. (L'osteoartrosi primaria generalizzata e il suo trattamento.) Amira, A. (1964). Rif. med., 78, 197. 34 refs.

Osteo-Arthritic Conditions in the Aged Patient. (Les affections ostéoarticulaires du sujet âgé.) Pequignot, $\mathbf{H}$., Caroit, M., Cremer, G., and Hassan, G. (1964). Rhumatologie, 16, 1. 5 figs.

Osteo-arthritis of the Hip and its Modern Surgical Treatment. (Die Koxarthrose und ihre heutige operative Behandlung.) Glogwoski, G. (1964). Münch. med. Wschr., 106, 823.8 figs.

Why and How should Osteo-arthritis of the Hip Joint be classified? (Pourquoi et comment classer les coxarthroses?) Ruelle, M., Dubois, J.-L., and Debeuckelaere, M. (1963). Rev. Rhum., 30, 802. 7 figs, 22 refs.

Surgical Relief of Hip Joint Pain. SANDER, S. (1964). Geriatrics, 19, 286.11 refs.
Surgical Indications in the Treatment of Osteo-arthritis of the Hip Joint. (Indications chirurgicales dans le traitement de la coxarthroses.) JUDET, R. (1963). J. belge Méd. phys. Rhum., 18, 301.

Periarthrosis of the Hip. (Periarthrosis coxae.) BREndSTR UP, P. (1964). Ugeskr. Lag., 126, 629. 11 refs.

Muscular Factor in Osteo-arthritis of the Hip. (Le facteur musculaire dans la coxarthrose.) WAGHEMACKer, R., Dumoulin, J., and SPy, E. (1963). Ann. Méd. phys., 6, 263.13 figs, 36 refs.

Rheumatoid Affections of the Hip Joint; a Radiological Study. (Les coxites rhumatismales: étude radiologique.) Verhaeghe, Lemaître, G., and LebeurRe, R. (1963). J. Radiol. Electrol., 44, 848. 4 figs.

Heredity and Osteo-arthritis of the Spine. Study of $\mathbf{8 0 0}$ Patients selected from among 1,467 Cases. NAvA, P., and SEDA, H. (1963). A.I.R. Arch. interamer. Rheum. (Rio de J.), 6, 525.7 refs.

Biomechanics in Relation to Osteo-arthritis of the Knee Joint. (Considérations bioméchaniques sur l'arthrose du genou.) Marchin, P. DE, MAQuet, P., and Simonet, J. (1963). Rev. Rhum., 30, 775. 14 figs, 3 refs.

Treatment of Osteo-arthritis of the Knee Joint. (Tratamiento de la artrosis de rodilla.) Orozco Delclus, R. (1964). Medicina (Madr.), 31, 137.

Experimental Osteo-arthritis in Guinea-pigs produced by Nonchromogenic Unclassified Mycobacteria. KuBIN, M., Kruml, J., and JANKU, A. (1964). Acta tuberc. pneumol. scand., 44, 159 . 7 figs, 12 refs.

Some Recent Work on Heberden's Nodes with a Personal Observation of the Limitation of Articular Lesions to the Healthy Side in a Spasmodic Hemiplegic. (Quelques travaux récents sur les nodosités d'Heberden avec une observation personnelle de limitation des lésions articulaires du côté sain chez une hémiplégique spasmodique.) FrançON, F. (1964). Rhumatologie, 16, 37.

\section{Spondylitis}

Changes in the Cervical Spine (Cervical Spondylitis) in Chronic Rheumatoid Arthritis and Ankylosing Spondylitis. (Veränderungen der Halswirbelsäule (Spondylitis cervicalis) bei der chronischenrheumatischen Polyarthritis und bei der Spondylitis ankylopoetica.) Schilling, F., Schacherl, M., Bopp, A., Gamp, A., and HAAS, J. P. (1963). Radiologie, 3, 483. 31 figs, bibl.

The authors of this paper from the Rheumatic Clinic, Bad Kreuznach, and the Institute of Clinical Radiology 
of the University of Mainz claim that the cervical spine is affected in rheumatoid arthritis more frequently than is generally realized. The most important signs of such involvement are marked osteoporosis, erosion of the endplates, erosive and destructive changes in the small intervertebral joints, generally not leading to fusion, and displacement of the vertebrae either at the atlanto-axial joint only or at multiple levels (step-ladder pattern). Loss of the intervertebral disk space with eventual fusion is often seen. The spinous process of the 7 th cervical vertebra may end in a sharp point, a characteristic sign seen only in severe forms of rheumatoid arthritis. The osteophytes which are prominent in osteoarthritis are not seen in rheumatoid arthritis, and reduction of the disk spaces in the latter condition is usually found at higher levels than in the former.

In juvenile rheumatoid arthritis the typical findings differ slightly from those of the adult type, the main characteristics being underdevelopment or destruction of the intervertebral disks with consequent vertebral fusion, ankylosis of the small intervertebral joints with band-like fusion of the neural arches, and arrest of development of the vertebral bodies and hypoplasia of the spinous processes. The changes again occur higher in the spine than in other conditions. Mandibular hypoplasia (birdface) is frequently combined with these cervical changes.

Ankylosing spondylitis of the cervical spine usually presents the characteristic features of the disease, but atypical forms do arise. One little known feature is the tendency for fractures of the cervical spine to occur, usually at the level of $\mathrm{C} 5$ and 6 or $\mathrm{C} 6$ and 7, from relatively slight trauma owing to the general rigidity of the spine. These fractures heal quickly and neurological signs are very rare. The "anterior" type of cervical spondylitis is an early form of ankylosing spondylitis in which there is a "squaring-up" of the vertebral bodies combined with anterior erosion. Erosion and atrophy of the odontoid process may be severe. F. M. Abeles

Ankylosing Spondylitis at the Beginning of the Century. (Gilbert Scott Memorial Oration.) Forestier, J. (1964). Rheumatism, 20, 28.

Ankylosing Spondylitis. Early Diagnosis. (Espondilite ancilosante. Diagnóstico precoce.) Verztman, L., Rubinstein, J., and Leite, N. (1964). J. bras. Med., 8, 53 . 12 figs, 32 refs.

On the Aetiology of Ankylosing Spondylitis. DONAHUE, P. M. (1964). Marquette med. Rev., 30, 15. 12 refs.

Backache from Osteitis of the Vertebral Bodies as the First Clinical Manifestation of Ankylosing Spondylitis. (Spondilalgia da osteite del corpo vertebrale, prima manifestazione clinica di una spondilartrite anchilosante.) VIARA, M. (1963). Reumatismo, 15, 467. 4 figs, 7 refs.
Considerations on the "Posterior Variety" of Ankylosing Spondylitis. (Considerazioni sulla "varietà posteriore" della spondilartrite anchilosante.) VIARA, M. (1963). Reumatismo, 15, 513.10 figs, 17 refs.

Chromosome Patterns in Irradiated and Non-irradiated Patients with Rheumatoid Spondylitis. Newcombe, D. S., and CoHen, A. S. (1963). Ann. intern. Med., 59, 859 . 1 fig., 13 refs

\section{Inflammatory Arthritides}

Rheumatic Monarthritis and Trauma. (Rheumatische Monarthritis und Trauma.) Franke, D., HuPE, K., and Fricke, R. (1964). Med. Welt (Berl.), 3, 132.

About 75 per cent. of all unilateral effusions into the knee joint are blood-stained and of traumatic origin. In the remaining 25 per cent. of cases the effusion is serous or serofibrinous, and in many of these it is clearly secondary to old cartilage trouble, degenerative joint disease, or other specific or non-specific causes. In other cases, amounting to about 10 per cent. of the total, the cause of a serous or serofibrinous effusion is not immediately apparent, though an underlying rheumatic cause may be suspected from the recurrent nature of the effusion, increase in erythrocyte sedimentation rate (E.S.R.), and marked changes in the serum electrophoretic pattern.

In this paper from the Medical and Surgical Clinics of the University of Marburg the authors report investigations carried out on thirty patients with primary serous effusions into a knee joint and on a control series of sixteen patients with definite traumatic effusions. Antistreptolysin titre estimations, Rose-Waaler and latex fixation tests, and sometimes measurements of the Creactive protein content were carried out both on serum and on fluid aspirated from the affected joints. In nine of the thirty cases of serous effusion there was an appreciable rise in the Rose-Waaler and latex fixation titres in both effusion and serum and in six others the antistreptolysin titres were elevated. Twelve of the thirty gave a history of trauma, but in only one case could any skin defect over the joint be detected 3 days after the alleged accident. In one of the sixteen control cases the RoseWaaler titre was slightly increased $(1: 32)$ in the joint fluid, though a negative result $(1: 8)$ was obtained with serum and the antistreptolysin titres were normal both in serum and effusion. However, the E.S.R. was markedly increased and closer questioning revealed a past history of rheumatoid arthritis. In the remaining fifteen cases all the tests gave negative results.

The differential diagnosis of non-traumatic effusion may present difficulty; routine synovial biopsy is of no help apart from ruling out tuberculosis and is inadvisable. A serous effusion into a knee joint, even in the presence of a history of trauma, should arouse suspicion of a rheumatic monarthritis. It may antedate the onset of classic rheumatoid arthritis by several years, and in such cases the patient, in addition to receiving appropriate therapy, should be kept under observation for a long time. D. Preiskel 
Synovectomy of the Knee in Rheumatoid Arthritis. Aidem, H. P., and BAKER, L. D. (1964). J. Amer. med. Ass., 187, 4.17 refs.

In a recent 10-year period at Duke University Medical Center, Durham, North Carolina, the synovial membrane was removed from the knee on 31 occasions in 23 patients with rheumatoid arthritis. In performing the operation, care was taken to preserve the fat pad which lies between the suprapatellar pouch and the femur. The menisci, if involved, were excised as was the patella, and after the operation the knee was immobilized in plaster, weightbearing being permitted as the joint became more comfortable.

The average follow-up period was 4 years. The results were classified as excellent in eleven instances, good in twelve, fair in one, and poor in two. In the remaining five instances the operation had been performed too recently for adequate assessment. The authors emphasize that this operation is suitable only for patients with inactive or moderately active disease in which destruction of the joint is not severe. Any fixed flexion deformity of the knee must be corrected before operation, since synovectomy itself will not correct contractures.

\section{Peter Ring}

Treatment of Acute Articular Rheumatism. (Le traitement actuel du rhumatisme articulaire aigu.) Aubertin, M. E. (1964). J. Méd. Bordeaux, 141, 417. 53 refs.

Infective Rheumatism. (I reumatismi infettivi.) Tolentino, P. (1963). Reumatismo, 15, 419.27 refs.

Rhizomelic Pseudopolyarthritis and Horton's Syndrome (Histamine Cephalgia). (Pseudo-polyarthrite rhizomélique (P.P.R.) et maladie de Horton.) CAYLA, J., Weissenbach, R., Basset, F., and Coste, F. (1964). Rev. Rhum., 31, 1. 4 figs, 16 refs.

Chronic Arthritis after Rheumatic Fever. Jaccoud's Syndrome. (Artritis cronica post-fiebre reumatica. Síndrome de Jaccoud.) Navarret, E. E., GlenNy, J. E., Moradei, C. O., and Marroquín, C. (1964). Rev. Asoc. méd. argent., 78, 62 . 6 figs, 7 refs.

Pyogenic Arthritis. (Artrite piogênica.) Houli, J., and KLEIN, B. (1964). J. bras. Med., 8, 62. 12 refs.

Osteo-arthropathies caused by Pneumatic Hammers. (Les ostéo-arthropathies des marteaux pneumatiques.) Ravault, P. P., Roche, L., Maîtrepierre, J., and Chaudy, J. (1963). Rev. Rhum., 30, 720. 10 figs, 2 refs.

Urethro-conjunctivo-synovial (Reiter's) Syndrome. (Syndrome uréthro-conjonctivo-synovial.) BOUREL, M., Lenoir, P., Morel, H., Gouffault, J., and PaWlotSKY, Y. (1964). Sem. Hôp. Paris, 40, 800. 15 refs.
Reiter's Syndrome in the Course of Diabetes. [In Polish.] Kaliszewicz, A., KolodziejczaK, A., and MaldyK, E. (1963). Wiad.lek., 16, 1221.

Variations in the Intra-articular Pressure of the Hip Joint in Injury and Disease. Soto-HALL, R., Johnson, L. H., and Johnson, R. A. (1964). J. Bone Jt Surg., 46-A, 509. 5 figs, 13 refs.

Transitory Synovitis of the Hip in Children. Mills, K. L. G. (1964). Postgrad. med. J., 40, 190.16 refs.

Inflammation of the Knee Joint. (Entzündungen des Kniegelenkes.)-EICHLER, J. (1964). Münch. med. Wschr., 106, 813. 12 figs, bibl.

\section{Gout}

Changes in Serum and Urinary Uric Acid with the Development of Symptomatic Gout. Ayvazian, J. H., and Ayvazian, L. F. (1963). J. clin. Invest., 42, 1835. 21 refs.

In this paper from the Veterans Administration Hospital, New York, the authors report studies of urinary uric acid excretion and serum uric acid levels in eleven gouty subjects, during symptomatic and asymptomatic phases of their disease. Greater excretion and renal clearance of uric acid were found in all while the disease was symptomatic. Serum levels of uric acid changed variably, rising in eight subjects, falling in two, and remaining unchanged in one.

It was recorded that all eleven subjects had absolute or relative leucocytosis during the symptomatic period and in five subjects so tested 24-hr urinary 17-hydroxycorticosteriod excretion was increased. Studies of urinary uric acid excretion and serum uric acid levels were then carried out on seven patients who had not gout but some other form of acute inflammatory disease. In them, serum uric acid levels were not raised, but uric acid excretion and renal clearance were increased.

The authors conclude that patients with gout have a greater excretion and clearance of uric acid while symptomatic, but that serum levels do not change predictably with symptoms. The cause of these changes is unknown, but the leucocytosis and increased 17-hydroxycorticosteroid excretion found during the phase of acute symptoms suggests the combined involvement of increased uric acid production and steroid-induced renal uricosuria. T. M. Chalmers

Diagnosis of Gout. (Efectuar la prueba d? la gota.) Françon, F. (1963). Arch. argent. Reum., 27, 88.

Gout in Japan. (La goutte au Japon.) SHICHIKAWA, K., and Komatsubara, Y. (1964). Rev. Rhum., 31, 13.

Treatment of Gout by alternating Therapy with Colchicine and Tanderil. (Le traitement de la goutte par la prise alternée de Colchicine et de Tanderil.) LENGLévy, J., David-Chaussé, J., and Picot, Cl. (1964). J. Méd. Bordeaux, 141, 375. 
Carpal Tunnel Syndrome of Gouty Origin. (Syndrome du canal carpien d'origine goutteuse.) DE SÈzE, S., and Phankim-Koupernik, M. (1964). Rev. Rhum., 31, 9 . 2 figs.

Involvement of the Hip Joint in Gout. (À propos de l'atteinte des hanches au cours de la goutte.) SERRE, H., Simon, L., and Claustre, J. (1963). Rev. Rhum., 30, 740 . 9 refs.

Gout and Diabetes. (Gôta e diaketes.) Verztman, L., and Santino Filho, F. (1964). J. bras. Med., 8, 66. 9 refs.

\section{Bone Disease}

Effects of aspirin and Corticosteriods on Paget's Disease of Bone. Henneman, P. H., Dull, T. A., Avioli, L. V., BAstomsky, C. H., and LYNCH, T. N. (1963). Trans. Stud. Coll. Phycns. Philad., 31, 10. 16 figs, 9 refs.

In this paper from the Seton Hall College of Medicine, New Jersey, the authors discuss the effect of aspirin in Paget's disease and compare it with earlier studies using cortisone in the same condition.

With each agent they found that both bone deposition and resorption were suppressed as judged from histological and calcium balance studies, together with urinary hydroxyproline estimations in the aspirin trials. In the case of cortisone, massive doses, of the order of 500 $1,000 \mathrm{mg}$. daily, were required if any effect was to be achieved, but aspirin at blood salicylate levels of 25-40 $\mathrm{mg}$. per $100 \mathrm{ml}$. gave the same result. What the longterm effects of aspirin on Paget's disease are it was not possible to state at the time of writing, but these encouraging initial results were felt to warrant further investigation.

A. Garner

Leukaemia with Osteo-articular Symptoms and Signs. Silverstein, M. N., and Kelly, P. J. (1963). Ann. intern. Med., 59, 637. 3 figs, 20 refs.

Bone and joint symptoms were prominent clinical features in 35 out of 450 patients with acute leukaemia seen at the Mayo Clinic over two 3-year periods. The incidence of osteo-articular symptoms was 13.9 per cent. in children, 3.9 per cent. in adults, and 7.7 per cent. in the entire group. The leukaemia was lymphatic in type in 21 of the 24 children; in adults lymphatic and myelogenous leukaemia were of equal frequency. The lower limb was involved twice as commonly as the upper, which in turn was involved twice as often as the spinal column. Pain was the main symptom and was constant or intermittent. Migratory joint pain occurred in fourteen patients, and in two others arthritis was confined to a single joint.

Radiological examination of twenty patients revealed osteo-articular lesions in nine out of twelve children and in three out of eight adults. The changes observed were osteolytic lesions, demineralization, juxta-epiphysial rarefaction, and periosteal elevation. In all 35 cases the differential leucocyte count showed some abnormality, and in 22 peripheral blood smears were strongly suggestive of acute leukaemia. Bone marrow examination was diagnostic in all cases. Of 23 patients with anaemia, twelve also had leucopenia and nine also had leucocytosis. There were five patients with leucopenia only and one with leucocytosis only. The haemogram in the remaining six was normal. The authors stress the importance of careful study of the peripheral blood in differentiating acute rheumatism from acute osteo-articular leukaemia.

$$
\text { J. L. Markson }
$$

Bone Resorption and Osteoporosis. Little, K. (1963). Lancet, 2, 752.12 figs, 47 refs.

In this paper the author reviews recent studies in osteoporosis carried out, for the most part, in Trueta's department at Oxford. They have been particularly concerned with disuse atrophy and the osteoporosis occurring in the elderly. Their major contributions have been, firstly, to produce experimental evidence indicating that in the osteoporosis of disuse there is vascular stasis, and, secondly, to demonstrate in human material that there are qualitative differences in the collagenous matrix around certain osteocytes in addition to a reduction in bone mass. It is argued that the former changes are in some way responsible for the latter. Furthermore, evidence is quoted suggesting that vascular stasis with distension of the capillary bed is a main cause of the pain in this condition.

That a similar mechanism to the one outlined above, subject to hormonal control, might operate in osteoporosis of the elderly is also discussed.

A. Garner

Corticosteroid Osteoporosis and Treatment with Anabolic

Hormone. [In English.] LuND, H. (1963). Acta med. scand., 174, 735. 11 refs.

Osteoporosis, which is a common complication of corticosteriod therapy, has been attributed by Albright (Ann. intern. Med., 1947, 27, 861) to a relative imbalance between anabolic and catabolic hormones. But although the administration of anabolic hormones (oestrogens and androgens) to patients with osteoporosis appears to relieve the pain, there is little evidence of any restitution of the density of the bones. At the Frederiksborg County Central Hospital, Hillerød, Denmark, a trial was carried out to determine whether the administration of anabolic hormones during long-term corticosteriod treatment has any effect on the incidence of osteoporosis. Of the 71 patients included in the trial, 21 had rheumatoid arthritis and fifty had other diseases. All were given corticosteroids for more than 6 months, and 37 received $25 \mathrm{mg}$. norandrosterone phenylpropionate intramuscularly every 2 weeks in addition. None had evidence of osteoporosis at the start of treatment. Radiographs of the vertebral column were taken at intervals of 6 months during treatment, and the degree of osteoporosis, if present, assessed by an independent observer.

Osteoporosis developed in 22 of the 38 patients receiving the anabolic steroid (six having one or more fractures of vertebrae) and in nineteen of the 33 treated with corticosteroids alone (one having a fractured 
vertebra). It is therefore concluded that norandrosterone in the dosage used does not prevent the development of corticosteriod osteoporosis.

[It would have been interesting to know what exact criteria for osteoporosis were used, as vertebral collapse occurred in such a small proportion of cases.]

Oswald Savage

Circumscribed Osteolytic Appearances in the Long Bones in Paget's Disease. (Les images ostéolytiques circonscrites des os longs au cours de la maladie de Paget.) Louyot, P., Gaucher, A., Jeanblanc, J., and Miquel, G. (1963). Rev. Rhum., 30, 831 . 8 figs, 7 refs.

Familial Forms of Paget's Disease of Bone. (Les formes familiales de la maladie osseuse de Paget.) Ravault, P. P., Lejeune, E., Robert, J. M., and Maîtrepierre, J. (1963). Rev. Rhum., 30, 824 . 3 figs, 43 refs.

Osteoporosis of Cushing's Disease. Three Cases treated with Bilateral Adrenalectomy. (L'ostéoporose de la maladie de Cushing. À propos de trois cas traités par surrénalectomie bilatérale.) VIGNON, G., GuINET, P. MÉGARD, M., and Graber-DuvernaY, B. (1963). Rev. Rhum., 30712.11 figs, 12 refs.

Dysostosis Epiphysarea Peripherica. HовоLтh, N., and Mune, O. (1963). Acta rheum. scand., 9, 269. 4 figs, 13 refs.

Primary Necrosis of the Head of the Femur in Adults. (L'osteonecrosi primitive della testa femorale dell' adulto.) Viara, M., and Mellini, M. (1963). Reumatismo, 15, 525 . 9 figs, bibl.

Aseptic Necrosis of the Femoral Heads and Cushing's Syndrome. (Ostéonécrose aseptique des têtes fémorales et syndrome de Cushing.) LouYot, P., and Gaucher, A. (1963). Rev. Rhum., 30, 720. 2 figs, 21 refs.

Necrosis of Bone due to Pressure. (Ostéonécroses barotraumatiques.) SICHÈRE, R. M. (1964). Rhumatologie, 16, 11 . 4 figs, 18 refs.

Clinical and Radiological Aspects of Dysplasia of the Hip Joint. (Le displasie dell'anca rilievi clinico-radiologici.) Troysi, G., and Bray, E. (1963). Reumatismo, 15, 538 . 15 figs, bibl.

Two New Observations on Diffuse Articular Chondrocalcinosis. (Deux nouvelles observations de chondrocalcinose articulaire diffuse.) COMMANDRE, $F$. Lecomte, P., Taramasco, H., and Vedel, J.-P. (1964). Rhumatologie, 16, 27.11 figs, 22 refs.

\section{Non-articular Rheumatism}

Nerve Fibre Size in the Carpal Tunnel Syndrome. Thomas, P. K., and Fullerton, P. M. (1963). J. Neurol. Neurosurg. Psychiat., 26, 520. 5 figs, 28 refs.

[Median nerve compression in the carpal tunnel is often diagnosed nowadays, but detailed histological studies of the condition using modern techniques have not hitherto been reported. The only previous description of the pathology of the condition is given in a paper over 50 years old (Marie and Foix, 1913).]

The present authors describe measurements of the diameter of myelinated nerve fibres in both median nerves in a patient with the carpal tunnel syndrome who died of an unrelated disorder. The patient had prominent symptoms and signs in the right hand and only mild symptoms in the left. Conduction time in the motor nerve fibres to the abductor pollicis brevis was reduced below the wrist on the right but was normal on the left. There was also some slowing of conduction in the right forearm.

Sections of the median nerves were examined at the mid-forearm level, $1 \mathrm{~cm}$. above the flexor retinaculum and under the retinaculum. Sections were also examined of the digital nerves, on both sides. Fibre size did not differ between the right and left sides at the mid-forearm level, but showed some reduction $1 \mathrm{~cm}$. above the retinaculum on the right. Under the retinaculum, there was a striking reduction in fibre size on both sides, particularly on the right. The digital nerves on the right showed a reduction in fibre diameter as compared with the left, but fibre size was greater in the digital nerves on both sides than under the retinaculum.

The significance of these changes is discussed in relation to the results of experimental nerve constrictions in animals, and in relation to the changes in nerve conduction seen in the carpal tunnel syndrome.

C. Pallis

Haemangiomatosis of the Ulna and Flexor Muscles of the Forearm with Secondary Flexion Contracture of the Wrist and Hand. Carpenter, E. B., and Strawn, L. M. (1963). J. Bone Jt Surg., 45A, 1472. 8 figs, 37 refs.

In this paper from the Medical College of Virginia, the authors report a single case displaying the unusual combination of haemangiomatosis in both bone and adjacent skeletal muscle.

The patient, a young girl aged 13 years, presented with a history of pain and enlargement of the flexor aspect of the forearm, with flexion contracture of the wrist and fingers. The $x$-ray findings, showing subperiosteal thickening of the ulna, suggested a diagnosis of chronic osteomyelitis, and a biopsy taken 3 years before, at a different medical centre at the onset of symptoms, had apparently confirmed this. However, in order to exclude a neoplasm, the authors undertook surgical exploration of the forearm, and found two haemangiomatous lesions in the common flexor muscle mass and in the ulna underlying the muscle. Histological examination of the 
excised parts confirmed both the diagnosis of haemangioma and the independent nature of the lesions. The patient appears to have had a remarkable recovery of function in the hand after the operation.

The authors include a well-annotated review of the pathology of bone and muscle haemangiomata. R. A. Stockwell

Observations on a New Muscle Relaxant in Non-articular Rheumatism. ShaH, J. R., and TalwalkaR, C. V. (1964). J. Indian med. Prof., 10, 4842. 9 refs.

Surgical Treatment of Scapulo-humeral Periarthritis. (Chirurgie de la périarthrite scapulohumérale.) Claessens, H. (1963). J. belge Méd. phys. Rhum., 18, 296.

Scapulo-costal Syndrome. (Sindrome escapulo costal.) Juárez, C., and Moyano, A. G. (1963). Bol. méx. Reum., 3, 26. 4 refs.

Dupuytren's Disease. Contracture of the Palmar Aponeuroses. A Series of 378 Cases observed in a Large-scale Study. (La maladie de Dupuytren. Rétraction de l'aponévrose palmaire. Une série de 378 cas observés dans une grande entreprise). CHANUT, J.-C. (1964). Rev. Rhum., 31, 24.

Method for Measuring Swelling of Hands and Feet. Part I. Smyth, C. J., Velayos, E. E., and Hlad, C. J., JR. (1963). Acta rheum. scand., 9, 293. 3 figs, 3 refs.

II. Sмyth, C. J., Velayos, E. E., and Amoroso, C. (1963) Acta rheum. scand., 9, 306.5 figs, 4 refs.

Painful Shoulder due to Vertebral Insufficiency. (Espalda dolorosa por insuficiencia vertebral.) SAlas Heredia, J. (1963). Bol. méx. Reum., 3, 21.

Dynamic Treatment of the Low Back Strain Syndrome. WoOdheAd, B. H., and Fowler, J. R. (1964). Canad. med. Ass. J., 90, 1152.19 refs.

\section{Pararheumatic (Collagen) Diseases}

Pulmonary Function in Scleroderma. Ritchie, B. (1964). Thorax, 19, 28.6 figs, 36 refs.

This paper from the Royal Melbourne Hospital reports extensive studies of pulmonary function in 22 patients with scleroderma and correlates the findings with the clinical, radiological, electrocardiographic, and pathological findings. The symptoms in these cases had been present for 2 to 36 years. Ten of the patients gave a history of having had a cough with mucoid sputum for 2 to 12 years and three had had pleurisy. A chest expansion of less than $5 \mathrm{~cm}$. was noted in twelve patients, and nine of these had no changes in the skin of the chest wall. Crepitations were present in fourteen patients. Radiological abnormalities consisting of bilateral basal reticular and nodular shadowing were found in the lung parenchyma of six patients. Electrocardiographic abnormalities were observed in five patients, two having right bundle-branch block and three right ventricular hypertrophy. There was abnormality of pulmonary function in all except one of the 22 patients, seven showing a single-defect (four an increased ventilatory response to excercise, two a reduced diffusing capacity of the lungs for carbon monoxide, and one lowered pulmonary compliance). In twelve patients the vital capacity was reduced below 80 per cent. of the predicted value. The forced expiratory volume in one second (F.E.V.1) was reduced below 70 per cent. of the vital capacity in two patients, and in three a 10 per cent. increase in the F.E.V.1 was found after application of a bronchodilator aerosol. The total lung capacity was below 80 per cent. of the predicted value in seven patients, all of whom had a reduced vital capacity, residual volume, and functional residual capacity. Three others had a significant increase in functional residual capacity and residual volume, and in one of these there was evidence of airway obstruction. Of the twenty patients so tested, eleven had an abnormally high ventilatory response to exercise (34 litres a minute); three showed a normal ventilatory response, but complained of severe impairment of exercise tolerance.

Specimens of lung were examined histologically in two cases. In one patient who died after the rapid development of malignant hypertension with renal failure cystic spaces which were lined with bronchiolar epithelium were seen at necropsy to replace the normal alveolar architecture. The interstitial tissue contained increased amounts of fibrous tissue. Patchy myocardial fibrosis with normal coronary vessels was an additional feature. Lung biopsy in the second case revealed replacement of normal lung architecture by cysts lined with columnar epithelium. The interstitial tissue showed a marked increase in smooth muscle, fibrous tissue, and hyaline material. Peribronchial giant-cell systems with vacuolated cytoplasm were scattered throughout. Some pulmonary vessels showed proliferation of the media and intima, but no evidence of fibrinoid necrosis.

In this study no correlation was found between the extent of the cutaneous lesions and the radiological changes in the lungs with functional impairment, nor was there any evidence that cutaneous lesions of the chest wall were responsible for the pulmonary changes.

Kenneth M. A. Perry

Roentgenographic and Pathologic Aspects of Intestinal Scleroderma. Heinz, E. R., SteinberG, A. J., and SACKNer, M. A. (1963). Ann. intern. Med., 59, 822. 4 figs, 10 refs.

This paper from the Philadelphia General Hospital, Pennsylvania, describes the radiological signs of intestinal scleroderma, some of which are highly characteristic and may indicate the correct diagnosis, particularly when skin changes are absent or equivocal. The 46 cases of the disease admitted to the hospital between 1952 and 1962 are analysed. Mention is made of the well-known appearance of the atonic oesophagus which empties only 
with the aid of gravity and which may be a useful corroborative finding.

Of the 32 small-bowel radiographs available for study, fourteen ( 44 per cent.) presented abnormal appearances. In eleven cases there was dilatation of the duodenum as far as the mid-point of its third part; the dilated portion was hypomotile and retained barium up to 24 hours. In five of these cases in which pathological examination had been possible no mechanical obstruction was found and histologically there was focal atrophy of smooth muscle with fibrous-tissue replacement. The dilatation associated with scleroderma may be differentiated radiologically from that due to obstruction by the superior mesenteric artery, in which condition hypermotility is seen and the dilated duodenum empties while the patient is in the prone position. Of the cases showing duodenal dilatation, seven also had abnormalities in the remainder of the small bowel; these consisted of dilated loops, areas of narrowing, spiculation, and hypomotility. In three cases with a normal duodenum these changes were also present in the remainder of the small towel.

Of the nineteen patients who had had barium enema examination, ten showed multiple, characteristically square-shaped diverticula with wide necks, unlike the narrow-necked, globular colonic diverticula commonly seen. The authors state that these square-shaped diverticula, which may be distributed from the hepatic flexure to the recto-sigmoid junction, are apparently specific for scleroderma. In three patients in whom histological examination of the intestine was possible it was found that all the coats of the colonic wall were present in the diverticula and that there was almost complete replacement of smooth muscle in the diverticula by dense connective tissue.

Michael C. Winter

\section{Adrenal Medullary Function in the Connective Tissue Disorders. Fruehan, A. E., and Frawley, T. F.} (1963). Arthr. and Rheum., 6, 698. 1 fig., 21 refs.

It was reported by Michotte (Acta med. scand., 1958, 162, Suppl. 341, 101) that in patients with rheumatoid arthritis (R.A.) the 24-hour urinary excretion of noradrenaline was decreased and that of adrenaline increased, with reversal of the normal noradrenaline:adrenaline excretion ratio ( $\mathrm{N}: \mathrm{A}$ ratio). These changes were reversed by treatment with hydrocortisone or by intravenous procaine, which is known to inhibit the activity of monoamine oxidase, one of the enzymes concerned in the breakdown of the catecholamines. He therefore suggested that in R.A. monoamine oxidase activity is increased, with increase in the destruction of noradrenaline and reversal of the N:A ratio. As neither Michotte nor subsequent workers who have failed to confirm his results carried out control investigations on healthy controls or patients with other diseases the present authors, at Albany Medical Center Hospital, Albany, New York, have studied the excretion of adrenaline, noradrenaline, and certain of their degradation products in eleven healthy control subjects, nine patients with R.A., five patients with systemic lupus erythematosus (S.L.E.), eleven patients with other rheumatic diseases, and twelve patients with various acute or chronic non-rheumatic diseases. In each case 24-hour specimens of urine were collected and their content of adrenaline, noradrenaline, 3-methoxy-4-hydroxymandelic acid (VMA), and metanephrine-normetanephrine (MN) dertermined.

In the nine cases of rheumatoid arthritis the mean values for both the catecholamines and their metabolites were less than in the control group, but the difference was statistically significant only in the case of adrenaline and the $\mathbf{N}$ :A ratio was not reversed. In the five cases of S.L.E. no significant differences from the control values could be found and treatment with steroids and antimalarial drugs did not appear to affect the results. In the eleven cases of other rheumatic diseases the mean figures for VMA and MN excretion were significantly reduced, but no other abnormality was found. In the twelve cases of non-rheumatic diseases the mean values were all within normal range.

The authors conclude that there is no evidence of increased monamine oxidase activity (which would be expected to result in increased VMA excretion) in rheumatoid arthritis or any of the other conditions studied. Possible explanations for the diminished excretion of VMA and MN in cases of rheumatic diseases other than R.A. and S.L.E. are discussed. E. G. L. Bywaters

"Lupoid Hepatitis" Syndrome. (Das Syndrom der "lupoiden Hepatitis".) HARDERS, H., and Dölle, W. (1963). Gastroenterologia (Basel), 100, 220. 5 figs, bibl.

From the University Hospital, Hamburg, the authors report four cases of chronic liver disease in which antibodies against cell nuclei were detected in the blood by the immunofluorescence technique. In two cases the result of the L.E.-cell test was positive. They describe the characteristic features of lupoid hepatitis as the occurrence of antinuclear antibodies and an increased $\gamma$-globulin level in the blood and "piecemeal" necrosis of the liver with lymphocyte and plasma-cell infiltration, together with systemic manifestations such as arthritis, skin rashes, colitis, pleurisy, thrombocytopenia, and haemolytic anaemia. The condition occurs predominantly in women $(4: 1)$ and the average age of onset is about 30 years. The patient's condition may be improved by treatment with cortisone and 6-mercaptopurine.

The authors note that hepatic insufficiency did not occur in thirteen cases of systemic lupus erythematosus which they studied, and they discuss the question whether the occurrence of antinuclear factor in patients with lupoid hepatitis is part of the pattern of systemic lupus erythematosus, part of a distinct autoimmune disease of the liver, or merely secondary to liver damage.

[There is an excellent bibliography]. G. L. Asherson

Acute Oliguric Renal Failure in Acute Glomerulonephritis and Polyarteritis Nodosa. HARrison, C. V., LoughRIDGe, L. W., and Milne, M. D. (1964). Quart. J. Med., 33, 39.12 figs, 13 refs.

In this paper the clinical and pathological findings in 21 patients with acute glomerulonephritis and anuria or 
severe oliguria are compared with those in fourteen patients with acute oliguric renal failure due to the microscopic or "small-vessel" form of polyarteritis nodosa to show the close similarity between the two conditions. All the patients were admitted to Hammersmith Hospital, London, during the 39-month period December, 1957, to February, 1961, most having been referred from other hospitals for treatment by haemodialysis. The prognosis in both groups was very bad, all the patients with polyarteritis dying and only two of those with nephritis making a complete recovery though five others recovered partially. The outlook was worse for adults than for children. Renal biopsy was of value in establishing the presence of irreversible changes and so obviating the useless repetition of dialysis.

On clinical grounds the patients with nephritis could be divided into three groups-those who developed a diuresis with partial or complete recovery; those who died after a partial diuresis; and those who died without diuresis. The most severe pathological change-complete obliteration of Bowman's space-was commonest in the third group, but the findings in the first group showed that diuresis can occur despite severe glomerulitis, crescent formation, and even obliteration of some glomeruli. A purely clinical diagnosis of oliguric acute glomerulonephritis was usually more easily made in children than in adults; a history of preceding streptococcal infection was more common in the children and such clinical features as oedema and hypertension were often minimal or absent in the adults. In most cases the oliguria grew steadily worse, in contrast to the slow rise in urinary volume seen in the oliguric stage of acute tubular necrosis. In spite of this, however, the rates of clinical deterioration and of rise in blood urea level were slower in nephritis than in acute tubular necrosis, partly because of the absence of general tissue damage and shock and partly because of the higher concentration of urinary constituents other than sodium and chloride.

In the patients with polyarteritis nodosa the clinical picture closely resembled that of acute oliguric glomerulonephritis and the true diagnosis was suspected during life in only eight of the fourteen patients. In the two patients in whom the diagnosis was confirmed by renal biopsy, treatment with adrenocortical steroids produced no improvement in the lesions or in the clinical course. The renal lesions are less evenly distributed in this condition than in glomerulonephritis so that the sampling error in renal biopsy is greater, but since the clinical course and management of the two conditions are similar, differential diagnosis is not of great practical value.

D. A. K. Black

Chronic Discoid Lupus Erythematosus; a Study of 65 Patients and 65 Controls. Rothfield, N., MARCH, C. H., Miescher, P., and McEwen, C. (1963). New Engl.J. Med., 269, 1155.14 refs.

In order to study further the incidence of systemic involvement in chronic discoid lupus erythematosus the authors compared all 65 cases seen at the Skin and Cancer Clinic of the New York University Medical Center between 1950 and 1960 with a control group of dermato- logical patients matched for age, sex and race. Diagnosis was established clinically and was confirmed by biopsy in thirty cases. The patients were divided into two groups - those with localized (53 cases) and those with widespread disease, that is, with lesions below the neck (12 cases). The results of clinical examination and a variety of laboratory tests are tabulated together with general symptomatology in patients and control group, and the case histories of two patients considered to have systemic lupus erythematosus are given.

Significantly higher incidences of loss of weight and leucopenia were found in the patients with lupus erythematosus; certain other abnormalities were also observed more frequently in this group, but in numbers too small to be evaluated statistically, as they usually occurred as single abnormalities. These included Raynaud's phenomenon, convulsion, thrombophlebitis, splenomegaly, pericarditis, biological false positive serological reactions, high $\gamma$-globulin values in the zinc sulphate turbidity test, and presence of antinuclear antibodies and L.E.-cells. Arthralgia and arthritis and raised erythrocyte sedimentation rate were found to be of equal frequency in the two groups.

In discussing their findings the authors point out a fundamental difference in sex ratio between chronic discoid and systemic lupus erythematosus; in the 65 cases under review the female:male ratio was $1 \cdot 7: 1$, compared with $6 \cdot 5: 1$ in another series of 127 patients with systemic lupus. They conclude that "chronic discoid lupus erythematosus is a disorder with a sex ratio different from that in systemic lupus erythematosus, in which systemic involvement is slightly greater than that of a matched group of dermatological control patients". They suggest that chronic discoid and systemic lupus erythematosus might be disorders of a different nature, but with a common genetic background. Benjamin Schwartz

Diagnosis, Differential Diagnosis, and Treatment of the So-called Collagen Diseases in Childhood. (Zur Diagnose, Differentialdiagnose und Therapie der sogenannten Kollagenosen im Kindesalter.) AlTHOFF, H. (1964). Med. Welt (Stuttg.), No. 15, 838. 3 figs, 15 refs.

Neurological Symptoms in Collagen Diseases. (Nevrologiske symptomer ved kollagenoser.) KÅss, E. (1964). Nord. Med., 71, 581. 20 refs.

Relation of the Schönlein-Henoch Syndrome to the Collagen Diseases. (Zespół Schönleina-Henocha a kolagenozy.) Balukiewicz, I. (1964). Pediat. pol., 39, 133 . 3 figs, 15 refs.

Neurological Complications of the Schönlein-Henoch Syndrome. (Powikłania ze strony centralnego układu nerwowego w przebiegu zespołu Schönleina-Henocha.) Serejska, E., and Zeligowska, J. (1964). Pediat. pol., 39, 175. 14 refs.

Physiopathology of the Collagen Diseases. (Fisiopatologia das colagenoses.) DE PAOLA, D. (1964). J. bras. Med., 8, 27 . 8 figs, 42 refs. 
Dermatological Aspects of the Collagen Diseases. (Colagenoses: Aspectos dermatológicos.) PôRto, J. A. (1964). J. bras. Med., 8, 49 . 6 figs, 33 refs.

Nutrition and Collagen Disease. WendeL, H. F. (1964). Delaware med.J., 36, 78. 26 refs.

Polymyalgia Rheumatica-an Essay in Discipleship. Micks, R. H. (1964). J. Irish med. Ass., 54, 141. 5 refs.

Decreased Oxidative Deamination of Catecholamines associated with Clinical Scleroderma. BRUNJES, S., Arterberry, J. D., Shankel, S., and Johns, V. J., JR. (1964). Arthr. and Rheum., 7, 138. 1 fig., 48 refs.

Renal Lesions in Scleroderma. Franco, R., JimÉnez Diaz, C., and Oliva, H. (1963). Bull. Inst. med. Res. (Madr.), 16, 85. 7 figs, 7 refs.

Polyneuritis due to Polyarteritis Nodosa. (Polineuritis por panarteritis nudosa.) RUGIERO, H. R., TCHOULamjan, A., Rillo, G., and Golfera, H. (1964). Rev. Asoc. méd. argent., 78, 16.12 figs, 3 refs.

Experimental Production of a selectively Hepatic Periarteritis Nodosa. Selye, H., Gabbiani, G., and TuCHWEBer, B. (1964). Angiology, 15, $184.1 \mathrm{fig}$., 10 refs.

Psoriasis and Arthritis. (Kuszczyca a zmiany stawowe.) Kofler, A. (1963). Przegl. Derm., 50, 547. 10 refs.

Osteo-arthropathy in Young Patients with Psoriasis. (Osteo-artropatie in giovani affetti da psoriasi.) Melchionda, E., and Guarnera, M. (1963). Reumatismo, 15, 475 . 3 figs, 10 refs.

Familial Occurrence of Dermatomyositis. LAMBIE, J. A., and Duff, I. F. (1963). Ann. intern. Med., 59, 839. 2 figs, 35 refs.

Progressive Systemic Sclerosis. Rivelis, A. L. (1963). A.I.R. Arch. interamer. Rheum. (Rio de J.), 6, 496. 12 figs, 12 refs.

Some Thoughts on Lupus Erythematosus. (Einige Gedankan zum Lupus erythematodes.) DAMESHEK, W. (1964). Med. Klin., 59, 374.

Clinical Aspects of Systemic Lupus Erythematosus. (Aspectos clínicos del lupus eritematoso generalizado.) Gutiérrez-Moyano, A., Iturbe Zabaleta, I., and Palacios Bermúdez. R. (1963). Bol. méx. Reum., 3, 14.

Association of Systemic Lupus Erythematosus with Rheumatic Fever. (Associação do lúpus eritematoso sistêmico com a febre reumática.) DeMello Filho, J., PAPI, J. A., and BATISTA M. JANini, J. (1964). J. bras. Med., 8, 76. 19 figs, 28 refs.
Autoimmune Haemolytic Anaemia and Thrombocytopenic Purpura in Subacute Lupus Erythematosus. (Anemia emolítica e porpora trombocitopénica auto-immuni in corso di lupus eritematoso sub-acuto.) ANGELONI, G., Fagiolo, E., and Mastromonaco, A. (1963). Haematologica, 48, 757 . 3 figs.

Antinuclear Factors and their Relationship to the Activity and Severity of Systemic Lupus Erythematosus. (Antinukleárne faktory a ich vzťah $\mathbf{k}$ aktivite a agresii diseminovaného lupus erythematosus.) ŽIŤ̌AN, D. (1964). Čas. Lěk. čes., 103, 515.3 figs, 35 refs.

Laboratory Method for the Description and Evaluation of the L.E.-Phenomenon in Peripheral Blood. HAMmer, G. (1964). Scand. J. clin. Lab. Invest., 16, 61. 12 figs, 24 refs.

Demonstration of the L.E.-Factor by Immunofluorescence. (Průkaz le faktoru imunofluorescenčni metodou.) Kramář, J., Strejček, J., and Rejholec, V. (1964). Čas. Lék. čes., 103, 255. 3 figs, 7 refs.

Treatment of Lupus Nephropathy with 6-Mercaptopurine. (A lupus-nephropathiák gyógyítása 6-mercaptopurinnal.) Petrányi, G. (1964). Orv. Hetil., 105, 129. 8 refs.

Immunologic Nature of Antithrombin in the Course of Disseminated Lupus Erythematosus. HAWIGER, J., Hanicki, Z., and Struzik, T. (1964). Acta med. pol., 5, 53 . 3 figs, 37 refs.

Cryocoagulopathy with Presence of Immuno-antithrombin in the Course of Disseminated Lupus Erythematosus. Struzik, T., Hanicki, Z., HAWIGer, J., and BIERNACKA, B. (1964). Acta med. pol., 5, 61. 5 figs, 76 refs.

Diagnosis of Disseminated Lupus Erythematosus by the Intradermal Leucocyte Reaction. (Método de diagnóstico do lúpus eritematoso diseminado, utilizando-se a intradermo-reação com leucocites autologos.) Verztman. L., Gandelman, L., de Paola, D. and Estrella S. Borges, M. (1964). J. bras. Med., 8, 44. 2 figs, 3 refs.

Disseminated Lupus Erythematosus. (Lúpus eritematoso diseminado.) Verztman, L., Rubinstein, J., Leite, N., and Lederman, R. (1964). J. bras. Med., 8, 106. 38 refs.

Diagnosis of Acute Disseminated Lupus Erythematosus by Immunoflourescence. ( $\mathrm{O}$ diagnóstico do lúpus eritematoso agudo diseminado pelos métodos de imunofluorescência.) Corderro, A., and Costa, H. (1963). Gaz. méd. port., 14, 521. 4 figs, 7 refs. 


\section{Connective Tissue Studies}

Nature of the Connective Tissue Abiotrophy in the Marfan Syndrome. Bolande, R. P. (1963). Lab. Invest., 12, 1087. 7 figs, 18 refs.

This study of the ascending aorta and the endothelium of the left atrium in four infants and two adults with Marfan's syndrome confirms previous observations that in both sites there is an accumulation of amorphous intercellular material associated, in the aorta, with separation and disruption of the elastic elements.

On the basis of a histochemical study, the author concludes that the amorphous material consists mainly of chondroitin sulphate.

Electron photomicrographs of collagen fibres scraped from the affected aortas revealed no ultrastructural abnormality. The elastic fibres were also normal by this method.

J. Ball

Electron-microscope Studies of the Behaviour of the Collagen Fibrils of the Skin in Scleroderma. (Elektronenmikroskopische Untersuchungen über das Verhalten der Kollagen-fibrillen der Haut bei Sklerodermie). Rupec, M., and Braun-Falco, O. (1964). Arch. klin. exp. Derm., 218, 543.11 figs, 50 refs.

\section{Immunology and Serology}

Proteins of Serum and Oedema Fluid in Rheumatoid Arthritis. PARK, D. C., and Swinburne, K. (1964). Brit. med.J., 1,86. 4 figs, 9 refs.

An investigation was undertaken at the University of Leeds in an attempt to assess the cause of the oedema in the region of the feet and ankles which is often found in rheumatoid arthritis. Specimens of oedema fluid ( 0.5 to $1.0 \mathrm{ml}$.) were obtained, by introducing the tip of a Southey tube just under the skin to avoid contamination with blood, from eighteen patients with rheumatoid arthritis (complicated in one case by systemic lupus erythematosus and in another by amyloid disease) and from three control subjects (two with congestive heart failure and one with the oedema of hemiplegia). In each specimen the total protein concentration was estimated turbidimetrically and the electrophoretic pattern estimated visually. In all but one of the sixteen cases of uncomplicated rheumatoid arthritis the total protein content of the oedema fluid was less than $1 \mathrm{~g}$. per $100 \mathrm{ml}$. (mean $0.59 \mathrm{~g}$. per $100 \mathrm{ml}$.). In the case complicated by lupus erythematosus it was $2 \cdot 3 \mathrm{~g}$. per $100 \mathrm{ml}$. and in the case with amyloidosis it was $0.03 \mathrm{~g}$. per $100 \mathrm{ml}$. The control values in both cases of congestive heart failure were below $1 \mathrm{~g}$. per $100 \mathrm{ml}$. and in the case of hemiplegia it was $1.68 \mathrm{~g}$. per $100 \mathrm{ml}$. In each case of rheumatoid arthritis comparison of the electrophoretic pattern of the oedema-fluid proteins with that of the serum proteins showed that the relative increase in the large-molecular $\alpha_{2}$-globulin fraction found in the serum was not reflected in the oedema fluid, while the smaller-molecular $\alpha_{1}$-globulin fraction was relatively increased and there was also a much higher proportion of albumin in the oedema fluid.

The findings indicate that the oedema of rheumatoid arthritis falls into Group 1 of Crockett's classification
(Lancet, 1956, 2, 1179; Abstr. Wld Med., 1957, 21, 302) and is attributable to a disturbance of the capillary filtration-absorption equilibrium. Thus this oedema fluid is a transudate or a filtrate from a capillary endothelium which has a normal selective permeability to protein. There is no evidence to support the suggestion that the oedema in rheumatoid arthritis is inflammatory or allergic in origin. The exact mechanism of its production is, however, not as yet fully determined.

Harry Coke

Sero-negative and Sero-positive Rheumatoid Arthritis. Bland, J. H., and Brown, E. W. (1964). Ann. intern. Med., 60, 88. 1 fig., 11 refs.

A detailed comparison was made between 24 patients with rheumatoid arthritis whose response to the latexfixation test was consistently positive and 23 such patients in whom the test gave a negative result. All the patients had been followed up for 4 years or more at the Rheumatism Research Unit of the University of Vermont College of Medicine, Burlington. Among the serologically positive patients the division between the sexes was approximately equal, while in the sero-negative group females predominated in a ratio of $3: 1$. The seropositive patients more often had lesions in the metacarpophalangeal, metatarsophalangeal, ankle, subtaloid, and tarsal joints; they also more often had tendon lesions and subcutaneous nodules. The serum cholesterol level was significantly higher in the sero-negative group, but no difference was found between the two groups in serum protein level or in the cholesterol content and viscosity of joint fluids. Radiological evidence of involvament of the metacarpophalangeal and metatarsophalangeal joints was found significantly more often in the sero-positive patients.

The authors infer that the essential difference between the two groups is one of degree and that there is insufficient evidence for regarding sero-positive and seronegative rheumatoid arthritis as different diseases.

J.A. Cosh

Results of a Modification of the Inhibition Test in Combination with the Latex Drop Test in the Serological Diagnosis of Rheumatic Diseases. (Ergebnisse mit einer Modifikation des Inhibitionstests in Verbindung mit dem Latextropfentest zur serologischen Rheumadiagnostik.) MATHIES, H., and FladerER, M. (1963). Dtsch. med. Wschr., 88, 2391. 12 refs

From the Medical Polyclinic of the University of Munich the authors report their experience with a modification of the agglutination inhibition test of Ziff and others (Amer. J. Med., 1956, 20, 500; Abstr. Wld Med., $1956,20,387)$ in which the ability of serum from a case of suspected rheumatoid disease to inhibit an agglutination system with a known rheumatoid serum is compared with that of a normal serum by means of serial dilutions. At a certain titre the rheumatoid serum fails to inhibit agglutination, while the normal serum will still do so. Whole sera were used for this inhibition test, and the test system was a commercial preparation of latex particles coated with $\gamma$-globulin (Cohn's Fraction II) used as a drop test on slides. This test, together with the ordinary 
latex agglutination test, was carried out on sera from 90 patients with "chronic polyarthritis" and 54 healthy control subjects. The incidence of positive results in the former group was $87 \cdot 8$ per cent. with the inhibition test and only 58.9 per cent. with the agglutination test, but in the control group the incidence was $\mathbf{9 \cdot 3}$ per cent. with both tests.

[In the original inhibition test of Ziff and others euglobulin and not whole serum was used. In one case quoted euglobulin gave a positive reaction while whole serum did not, but the test system was sheep cell agglutination, and not latex fixation.]

G. Loewi

Rheumatoid Factor Properties of Hyperimmune Rabbit Sera. Christian, C. L. (1963). J. exp. Med., 118, 827. 9 figs, 32 refs.

This paper from the E. D. Faulkner Arthritis Clinic, New York, reports further studies of the "rheumatoid factor-like substance" (RFLS) induced in rabbits by prolonged immunization with bacterial antigens. Circulating antibodies to the bacterial antigen were separated from the RFLS by chromatography on DEAE cellulose and on Sephadex G.200. Antibodies to the bacteria were shown by ultracentrifugation to be associated with low molecular weight globulin but RFLS was present exclusively in macroglobulin fractions. On immunoelectrophoresis RFLS was less diffuse and more anodal in distribution than human gamma ${ }_{1} \mathrm{~m}$ globulin.

Sera containing RFLS were shown to have some isospecificity by titration with rabbit erythrocytes coated with four different rabbit isohaemagglutinins. The reaction of RFLS with coated erythrocytes was abolished or diminished when the sensitizing isohaemagglutinin had teen previously digested with pepsin.

$$
\text { W. R. M. Alexander }
$$

Immunological Specificity of the Rheumatoid Factor in Primary Chronic Polyarthritis. (Die immunologische Spezifität der Rheumafaktoren der primär-chronischen Polyarthritis.) DeICHER, H. (1964). Klin. Wschr., 42, 313. 9 figs, 57 refs.

Rheumatoid Factors; Ubiquity and Specificity. BrooKs, G. W., and СовB, S. (1964). Rheumatism, 20, 43. 36 refs.

Characteristic Serological Findings and their Pathogenetic Significance in Rheumatic Disease of the Heart and Joints. (Charakteristische serologische Befunde und deren pathogenetische Beceutung bei rheumatischen Herz- und Gelenkserkrankungen.) STEFFEN, C. (1964). Wien. med. Wschr., 114, 173.32 refs.

Serum Protein Electrophoresis in Rheumatic Fever. (Lo studio elettroforetico delle proteine seriche nella malattia reumatica.) Vecchio, C., and Zaverio, S. 1964). Arch. E. Maragliano Pat. Clin., 20, 107. 13 refs.
Correlation between Mucoproteinaemia and the Erythrocyte Sedimentation Rate in Children with Rheumatism. (Correlación entre mucoproteinemia y velocidad de eritrosedimentación en niños reumáticas). MIYAKAWA, F. Y. (1964). Clin. y Lab., 77, 103. 4 figs, 45 refs.

Behaviour of Alpha-seromucoid Acid (Wenzler's Orrhosomucoid) in Paediatrics. Part 2. (Ricerche in campo pediatrico sul comportamento del sieromucoide acido alfa (orosomucoide di Winzler). II.) BonO, G., and Crosato, M. (1964). Minerva pediat., 16, 77. 4 figs, bibl.

Evolution of the Anti-Gm Substances and of the Reactivity of Rheumatoid Sera for Human Red Cells sensitized with three Different Anti-Rh Sera or Immune Rabbit Sera and for F. II Latex. JAcQueline, F., PodliaChOuk, L., and EyQuem, A. (1964). Arthr. and Rheum., 7, 110. 4 figs, 13 refs.

The Haemotological, Clinical, and Radiological Characteristics of cases of Sero-negative Rheumatoid Arthritis. (Sulle caratteristiche cliniche, ematologiche e radiologiche dei casi di artrite reumatoide sierologicamente negativi.) VIARA, M. (1963). Reumatismo, 15, 504. 11 refs.

Variations in the Waaler-Rose reaction in the course of Rheumatoid Arthritis. (Les variations de la réaction de Waaler-Rose au cours de l'évolution des polyarthrites rhumatoides.) PASQuier, P.DU, DAvidChaussé, J., and Kervella, A. (1963). Rev. Rhum., 30, 706 . 9 figs, 18 refs.

Modification of the Waaler-Rose reaction with Human Group-0 Rh + sensitized erythrocytes. (Modificazione della reazione di Waaler-Rose con globuli rossi umani $0 \mathrm{Rh}+$ sensibilizzati (secondo Valkenburg).) CARCASSI A., Saletti, M., and Pianigiani, A. (1963). Ann. Sclavo, 5, 857. 7 refs.

Biochemical and Immunological Study of a Serum with an Antistreptolysin-0 titre of one million Todd units. (Étude biochemique et immunologique d'un sérum titrant 1 million d'unités Todd en antistreptolysine 0 .) Badin, J., and Cabau, N. (1964). Rev. Rhum., 31, 17. 3 figs, 13 refs.

Antistreptococcal Antibodies in Rheumatoid Arthritis. (Gli anticorpi antistreptococcici nella artrite reumatoide.) Pianigiani, A., and Pianigiani, M. (1963). Ann. Sclavo, 5, 851. 2 figs, 11 refs.

Comparative Study of the Diagnostic Value of the Antistreptolysin Titre, the Erythrocyte Sedimentation Rate, and the Hyland R.A. Test in Rheumatoid Arthritis. (Studio comparativo sulla attività diagnostica del tasso antistreptolisinico, della velocità di sedimentazione e del RA-test nella artrite reumatoide.) REBECCHI, M. GotTI, A., and BenedetTi, L. (1963). Boll. Soc. med.chir. Modena, 43, 467.14 refs. 
Antinuclear Antibodies. (Anticorps antinucléaires.) Thivolet, J., and KratchKo, A. (1964). Ann. Inst. Pasteur, 106, 679. 23 refs.

Comparison between a "Global" Antinuclear Reaction (Antinuclear Fluorescence) and a "Partial" Antinuclear Reaction (Latex-deoxyribonucleoprotein) in Systemic Lupus Erythematosus and Other Diseases. (Confronto tra una reazione antinucleare "globale" (fluorescenza antinucleare) ed una "parziale" (latice-desossiribonucleoproteina) nel lupus eritematoso sistemico ed in altre malattie.) BonOMO, L., TURSI, A., and DEL ZorTI, G. (1963). Reumatismo, 15, 426. 2 figs, 28 refs.

Immunology of Collagen Diseases. (Immunologia delle collagenopatie.) Cavallero, C., and Chiappino, G. (1963). Ann. Sclavo, 5, 717. 9 figs, 32 refs.

\section{Biochemical Studies}

Androgen Release and Synthesis in vitro by Human Adult Adrenal Glands. CoHN, G. L., and Mulraw, P. J. (1963). J. clin. Invest., 42, 64 . 2 figs, 53 refs.

In this communication from Yale University, the authors report:

(i) The isolation, measurement, and identification of adrenal androgens released into the incubation media with slices alone, and with the addition of radio-active steroid precursors;

(ii) The in vitro effect of adrenocorticotrophin (ACTH) on androgen release and substrate conversion.

In addition, data are presented for the pathways of adrenal androgen synthesis in "normal", hyperplastic and adenomatous tissues.

Methods are described for incubation technique for adrenal slices, for the addition of radioactive substrates to the incubation media, for the separation and measurement of steroids released, and for the identification of such steroids.

These studies demonstrate that fresh human adult "normal", atrophic, "hypertensive", hyperplastic, adenomatous, and carcinomatous tissue slices release dehydroepiandrosterone, androstenedione, and $11 \beta$-hydroxyandrostenedione into the media after 3 hours' incubation in Krebs-Ringer bicarbonate buffer fortified with glucose. The addition of ACTH to the system increases $11 \beta$-hydroxyandrostenedione release in all tissues, but does not stimulate dehydroepiandrosterone and androstenedione release.

The data presented for the possible pathways of adrenal androgen synthesis in "normal", hyperplastic, and adenomatous tissues suggest that adrenal androgens are converted predominantly from $17 \alpha$-hydroxypregnenolone $\rightarrow$ dehydroepiandrosterone $\rightarrow$ androstenedione $\rightarrow 11 \beta$-hydroxyandrostenedione rather than from progesterone $\rightarrow$ androstenedione $\rightarrow 11 \beta$-hydroxyandrostenedione.
Morquio's Disease; an Abnormality of Mucopolysaccharide Metabolism. RoBins, M. M., Stevens, H. F., and Linker, A. (1963). J. Pediat., 62, 881. 5 figs, 46 refs.

Patients with the classical features of Morquio's disease are readily distinguishable on clinical grounds from those with Hurler's disease by the presence of corneal opacities, deafness, hepatosplenomegaly, progressive mental deterioration, cardiovascular changes, thickening of the skin, and gargoyle facies in the latter; the presence of intracytoplasmic stippling in polymorphonuclear leukocyte cells (Reilly granules) and the mucopolysaccharides, chondroitin sulphuric acid B, and heparin monosulphuric acid in the urine have also been used to differentiate Hurler's disease from other hereditary disorders of connective tissue. Recently, however, more cases have been described showing the clinical manifestations of Morquio's disease with corneal opacities, deafness, Reilly granules, and mucopolysaccharides in the urine. To date, these have been considered as a separate entity.

This paper describes a clinical case of Morquio's disease in whom slit-lamp examination revealed very early diffuse haziness of the cornea. Both peripheral and bone marrow polymorphonuclear leukocytes showed Reilly granules and the urine showed an excess of mucopolysaccharides later identified as keratosulphate which is found in very small amounts, if at all, in normal urines, or in the urine of patients with gargoylism. A review of the patient's siblings, parents, and some other close relatives was made; a sibling aged 8 months, who appeared normal, showed flattening of the vertebral bodies radiologically, and while there was no quantitative increase in mucopolysaccharide excretion she also excreted keratosulphate; at this time no Reilly granules were noted in the peripheral blood, but by the age of 12 months, 80 per cent. of the peripheral polymorphonuclear leukocytes had them.

The authors suggest that Morquio's disease is an inborn error in mucopolysaccharide metabolism, and they feel that it is not yet wise to make a new category for patients with evidence of abnormal mucopolysaccharide deposition, such as corneal opacities, deafness, or Reilly granules.

B. M. Ansell

Effect of Cortisone on Mucoprotein Secretion by Gastric Antrum of Dogs. Pathogenesis of Steroid Ulcer. Menguy, R., and Masters, Y. F. (1963). Surgery, 54, 19 . 3 figs, 21 refs.

The ulcerogenic effect of the steroid hormone of the adrenal cortex is now well recognized, but the mechanism of this effect is not-understood. The present paper from the Department of Surgery of Kentucky University stresses the importance of impaired secretion of mucus induced by these hormones.

Denervated antral pouches were constructed in six dogs and the secretion collected daily for a period of 3 hours. Control periods of 1-2 weeks alternated with similar periods during which the steroids were given by intra- 
muscular injections in a daily dose of $150 \mathrm{mg}$. A significant reduction was observed in the volume of the mucus secreted and in the total amount of non-dialysable mucosubstances present in the secretion. Analyses of the mucus for total nitrogen, hexose, hexosamine, and sialic acid also revealed qualitative changes, amongst which reduction of sialic acid was the most obvious. Similar studies with aspirin showed comparable but less pronounced effects.

In view of the known physical and buffering properties of gastric mucus, these observed changes are regarded by the authors as a major factor in the ulcerogenesis associated with steroid therapy.

L. E. Glynn

Rate of Adrenal Cortisol Production in Response to Maximal Stimulation with ACTH. Nugent, C. A., MacDiarmid, W. D., Nelson, A. R., and Tyler, F. H. (1963). J. clin. Endocr., 23, 684.

Although the secretion rate of cortisol during maximal stimulation with ACTH can be determined by isotopic methods, a practical non-isotopic method would also be useful. Previous methods based on urinary and plasma 17-hydroxycorticosteroid (17-OHCS) estimations have been subject to errors resulting from variations in cortisol disposal rate, protein-binding, and distribution volumes, while less than one-third of the metabolites of cortisol are detectable as 17-OHCS. To eliminate these sources of error, patients were studied on separate occasions while receiving constant infusions, firstly of ACTH and 2 days later, of cortisol after suppression of endogenous corticotropin secretion with $1 \mathrm{mg}$. dexamethasone given the previous night. The rate of cortisol infusion (110 $\mu \mathrm{g} . / \mathrm{kg}$. body weight $/ \mathrm{hr}$ for $6 \mathrm{hrs}$ ) was selected on the basis of previous studies, which had shown that it approximated the production rate of cortisol during a 6-hr period of maximal stimulation with ACTH. Plasma 17-OHCS determinations were done on samples taken before infusion, and at 5 and $6 \mathrm{hrs}$ after starting infusion. The efficiency with which adrenal cortisol production was suppressed by dexamethasone was checked in 106 normal subjects.

The plasma 17-OHCS concentrations at $5 \mathrm{hrs}$ in normal subjects were similar to the concentrations at $6 \mathrm{hrs}$ during both the ACTH and the cortisol infusions, and it was inferred that by this time the rate of cortisol disposal was equal to the rate of supply Since the mean 5- and 6-hr plasma 17-OHCS concentrations were the same during cortisol infusion as they were during ACTH infusion, it was concluded that the hourly rate at which these subjects produced cortisol in response to maximal stimulation with ACTH was equal to the rate of cortisol infusion. Patients with adrenocortical insufficiency and some patients with cirrhosis of the liver produced less cortisol than normal in response to ACTH, while patients with Cushing's syndrome produced more.

(No data are given on how the cortisol infusion rate of $110 \mu \mathrm{g} . / \mathrm{kg}$. $/ \mathrm{hr}$ was arrived at but presumably an isotopic method was used.)
Effect of Adrenocorticotrophin on Adrenal Protein Synthesis. FARESE, R. V., and REDDY, W. J. (1963). Endocrinology, 73, 294. 3 figs, 20 refs.

An increase of protein synthesis by cell free extracts of adrenal glands has been shown to follow injections of ACTH for 4 days before removal of the glands. The present study, from the Peter Bent Brigham Hospital, Boston, analyses the mechanism of this increase.

Protein synthesis was measured by the incorporation of ${ }^{14} \mathrm{C}$ glycine into the protein fraction obtained from the incubation mixture. Ultra centrifugal fractionation of the homogenized glands revealed that the increased activity that resulted from previous ACTH stimulation resided in the soluble cell fraction, that is in the supernatant after centrifugation at $105,000 \mathrm{~g}$. The increased activity was not the result of an increase in the amino acid activating system, nor in the transfer of the activated product to soluble RNA, but was entirely accounted for by increased activity of the transferase system which is responsible for the transfer of the amino acids from their soluble RNA carrier to the growing peptide chains. The increased activity of this system was not due to any increase of guanosine triphosphate or ATP.

$$
\text { L. E. Glynn }
$$

\section{Corticosteroid-Binding Globulin. Species Distribution and} Small-scale Purification. Seal, U. S., and Doe, R. P. (1963). Endocrinology, 73, 371. 1 fig., 29 refs.

Corticosteroid-binding globulin (CBG) was sought in the sera of 25 vertebrate species ranging from fish to man. It was found in all but no obvious correlation exists between its concentration and taxonomic position.

In each instance where tested the binding capacity was greater at $4^{\circ} \mathrm{C}$. than at $37^{\circ} \mathrm{C}$., was considerably reduced by heat at $60^{\circ} \mathrm{C}$. for $15 \mathrm{~min}$., and was more than doubled in pregnancy.

The unique properties of this binding globulin are well shown by its separability from other serum proteins on hydroxylapatite columns. This permits a considerable degree of purification. The purified material from several species was found to contain significant amounts of hexose, hexosamine, fucose, and sialic acid.

$$
\text { L. E. Glynn }
$$

Folic-acid Deficiency in Rheumatoid Arthritis. Gough, K. R., McCarthy, C., Read, A. E., Mollin, D. L., and WATERS, A. H. (1964). Brit. med. J., 1, 212.6 figs, 32 refs.

This paper reports a study of six patients suffering from rheumatoid arthritis associated with megaloblastic anaemia, four of whom were admitted to Hammersmith Hospital, London, and two to Bristol Royal Infirmary. There were two males and four females aged between 38 and 70. In five cases the anaemia was attributed to deficiency of folic acid, and in these cases treatment with folic acid produced a good response. In the remaining patient tests revealed a subnormal serum level of vitamin $B_{12}$ as well as folic acid deficiency. Diminished intestinal absorption of vitamin $\mathbf{B}_{12}$ was detected in three cases. 
Further tests were carried out in 46 cases of rheumatoid arthritis selected at random from the records of the Bristol Royal Infirmary and the findings compared with those obtained in a control series of 57 healthy subjects. Of the 46 patients with rheumatoid arthritis, thirty showed biochemical evidence of folic acid deficiency; significantly lower haemoglobin concentrations were also found in the patients compared with the controls.

In the light of their experience so far the authors do not consider that folic acid deficiency is a major factor in the aetiology of the anaemia of rheumatoid arthritis. At the same time it would appear that deficiency of folic acid may result in glossitis, sore tongue, and lack of well-being in patients with rheumatoid arthritis. Barbiturate therapy may impede the utilization of folic acid. Deficiency of folic acid in rheumatoid arthritis can be relieved by the daily administration of 100 to $200 \mu \mathrm{g}$. of the acid. With this dosage subacute combined degeneration is not likely to develop. In larger doses, however, the treatment may mask the haematological features of vitamin$\mathbf{B}_{12}$ deficiency, so that the patient may eventually show neurological complications rather than anaemia.

\section{A. Garland}

Urinary Cortisol Excretion as a Test of Adrenal Cortical Function. Harris, J. J., and Crane, M. G. (1964). Metabolism, 13, 45 . 22 refs.

Urinary cortisol determination is recognized as a useful aid in the diagnosis of Cushing's syndrome, but it has not been widely used in other conditions. This paper from the Loma Linda University School of Medicine, Los Angeles, reports a study of urinary cortisol levels in cases with adrenal cortical abnormalities and various other clinical conditions, both tefore and after the administration of corticotrophin.

The patients studied were suffering from Cushing's syndrome, hirsutism, obesity, Stein-Leventhal syndrome (polycystic ovaries), hypopituitarism, and Addison's disease; twelve healthy control subjects were also studied. Urinary cortisol determination involved extraction and paper chromatography first on the Zaffaroni chloroformformamide system and then on the Bush $\mathrm{C}$ system. Blue tetrazolium or phenylhydrazine sulphuric acid were used for estimation; the two methods gave results in good agreement.

Patients with Cushing's syndrome showed increases to considerably greater than normal values in urinary cortisol levels after corticotrophin administration; in two cases the raised excretion rate persisted after corticotrophin withdrawal. Some cases of hirsutism showed an increased response, but a number of values were within the normal range, as were those of the obese subjects. Hypopituitarism, Addison's disease, and Stein-Leventhal syndrome were associated with a low urinary cortisol value and lack of or a diminished response to corticotrophin.

The authors conclude that the urinary cortisol level may be a more sensitive indicator of the effective level of circulating plasma cortisol than are measurements of other adrenal cortical metabolites; also the assay is of value in distinguishing between Cushing's syndrome and exogenous obesity. They consider that a very high baseline excretion is indicative of malignant disease, and that hirsute subjects with a raised response to corticotrophin may have adrenocortical hyperplasia. Nancy Gough

Studies of the Isoenzymes of Lactate Dehydrogenase in the Synovial Fluid. (Untersuchungen über die Isoenzyme der Lactat-Dehydrogenase in der Synovialflüssigkeit.) Greiling, H., Engels, G., and Kisters, R. (1964). Klin. Wschr., 42, 427.8 figs, 23 refs.

\section{Therapy}

Long-term Effects of Cortisone Therapy in Hypertrophy of the Thymus Gland. (Esiti a distanza della terapia cortisonica nelle ipertrofie timiche.) CAGNO, L. DI. (1963). Minerva pediat., 15, 1164.20 figs, 28 refs.

This paper reports the effects of corticosteroid therapy on hypertrophy of the thymus gland in twenty children (eleven male and nine female, aged 1 to 7 months) admitted to the Children's Clinic of the University of Turin. Most of the children presented with grave symptoms such as cyanotic crises, severe cough, and pyrexia. Six cases are fully described.

The administration of corticosteroids brought about a rapid involution of the thymus, but relapse occurred in practically all cases 15 to 30 days after discontinuation of the treatment. Various dosage regimens were used, but the incidence of relapses was not reduced by the use of larger doses of corticosteroids and the author considers that small doses in repeated short courses (for instance $1.5 \mathrm{mg}$. prednisolone $/ \mathrm{kg}$./day for 5 to 10 days) are the most effective. A favourable feature was that relapses were not usually associated with severe clinical symptoms. In the author's view, therefore, corticosteroid treatment seems advisable, especially in cases with severe symptoms. Radiotherapy should te reserved for cases of marked hypertrophy of the thymus which is refractory to corticosteroids.

A. J. Karlish

Sanatorium Managemnt of Rheumatoid Arthritis. Zeller, J. W., Waine, H., and Jellinek, K. (1963). J. Amer. med. Ass., 186, 1143.9 figs, 13 refs.

Between 1952 and 1958, 200 patients were admitted to Lakeville State Sanatorium, Middleboro, Massachusetts, with "classical" or "definite" rheumatoid arthritis. There were 154 females and 46 males, of whom 70 per cent. were over 40 years old and 54 per cent. had had the disease for 6 years or longer. Nearly half the patients stayed in the sanatorium for more than 6 months, and one-fifth for more than a year. The course of these 200 patients while in hospital is reviewed. [No follow-up after discharge was attempted.]

Patients were subjected to a sanatorium regimen, starting with rest and splintage for actively inflamed joints and gradual progression to more active measures. Pain was usually controlled by salicylates in full dosage; 119 patients were taking corticosteroids at the time of admission, but were weaned from this treatment as quickly 
as possible, and no patient was receiving corticosteroid therapy at the time of discharge.

Generally speaking, there was a considerable improvement in functional status on discharge, most marked in patients with disease of short duration. The least satisfactory results were noted in patients with long-standing advanced disease and in those who had been receiving corticosteroid therapy [probably to some extent the same group]. Four patients died in hospital, all with complications of corticosteroid therapy.

B. E. W. Mace

Foetal Effects of Steroid Therapy during Pregnancy. Hagler, S., Schultz, A., Hankin, H., and KUNSTADTER, R. H. (1963). Amer. J. Dis. Child., 106, 586. 9 refs.

The authors have reviewed the obstetrical records of the Michael Reese Hospital and Medical Center, Chicago, for the years 1954-8 in an attempt to determine to what extent the administration of oestrogens during pregnancy leads to feminization in male infants. During these 5 years there were 13,768 deliveries and 100 of the mothers had received steroid therapy, 99 of them oestrogen and progesterone compounds either separately or in combination. There were 102 babies, 56 females and 46 males (two sets of twins). Male pseudohermaphroditism or feminization of the genetic male was not observed in this series. Hypertrophy of the clitoris was noted at birth in one baby whose mother received norethisterone, $10 \mathrm{mg}$. daily, between the 2 nd and 6 th months, and one anencephalic monster probably of male genetic sex was born of a mother who received progesterone between the 4 th and 8th weeks of gestation. No other abnormalities were present in the remainder of the babies born to these women. It would appear that the critical time for the effect of steroid therapy on the foetus is between the 6th to 8 th week and the 12 th week, and abnormalities of the internal sexual organs or external genitalia are likely to occur only if the dosage is high during this time.

Winston Turner

Psoriasis following Administration of Antimalarial Drugs.

Kirschenbaum, M. B. (1963). J. Amer. med. Ass., 185, 1044.3 refs.

A 30-year-old male developed psoriasis one week after completing 12 days' antimalarial treatment with primaquine diphosphate $26.3 \mathrm{mg}$. daily. For the preceding 6 months $500 \mathrm{mg}$. chloroquine phosphate had been given weekly as a malarial suppressive but with no ill-effects. The patient's father had suffered from psoriasis but the patient had hitherto been clear.

The author refers to numerous records of antimalarial drugs, usually chloroquine, causing exacerbations, often severe, of pre-existing psoriasis. In most instances the daily dosage of chloroquine had contained not less than $150 \mathrm{mg}$. chloroquine as base. He suggests that in his patient the intensive dosage of Primaquine brought to light a latent psoriasis which had not been made evident with the smaller suppressive dosage of chloroquine but which may have been a contributory cause. With the widespread use of chloroquine it is possible that psoriasis may not infrequently present thus.

H.J. Wallace
Studies on an Intermittant Corticosteroid Dosage Regimen. HARTER, J. G., ReDDY, W. J., and ThORN, G. W. (1963). New Engl. J. Med., 269, 591. 8 figs, 15 refs.

Prof. Thorn and his colleagues at the Harvard Medical School here present their results of several years' experience in treating patients with corticosteroids by an intermittent instead of the usual divided daily dosage regimen. Trial and error showed that the optimal spacing is a single dose at breakfast time every other day. The total dose per 48 hours, however, is the same as that required for comparable control of symptoms by the traditional method. The great advantage of the new method, clearly brought out in this present study, is the reduction in sideeffects and the maintenance of the pituitary-adrenal axis in a normal functioning state. The ability of these nondepressed adrenals to respond to common stressful situations is emphasized by the absence of withdrawal symptoms or the need for increased steroid in the presence of mild infection.

L. E. Glynn

Cataract observed after Treatment with Long-term Corticosteroids. [In Japanese with English Summary.] Masuda, Y., and Nishio, T. (1963). Acta Soc. ophthal. jap., 67, 828. 6 figs, 11 refs.

In a patient in whom corticosteroids had been used for 7 years, a capsular cataract was observed. Among fourteen patients treated with steroids for one year or more, one patient showed a posterior capsular cataract. Y. Mitsui

Cataracts in Asthmatics treated with Corticosteroids. Leibold, J. E., and Itkin, I. H. (1963). J. Amer. med. Ass., 185, 448.6 refs.

A group of 220 in-patients at the National Jewish Hospital at Denver were examined to determine the incidence of posterior subcapsular cataracts. 72 of these were patients with asthma and were between the ages of 8 and 65 years. 48 of these were having long-term systemic steroid therapy. No posterior subcapsular cataracts were found in the 48 patients having steroid therapy, though there were some lens opacities in eight steroid-treated patients and in two who had never had corticosteroids.

The authors conclude that treatment with oral steroids is not likely to cause cataracts in asthmatic patients.

Oswald Savage

Indications and Contraindications for Cortisol Derivatives in Chronic Rheumatoid Disease. (Les indications et les contre-indications des dérivés du cortisol dans les affections rhumatismales chroniques.) DelachauX, A. (1964). Rev. méd. Suisse rom., 84, 3. 6 refs.

Indications and Contraindications for Cortisol and its Derivatives in Paediatrics. (Les indications et les contre-indications du cortisol et de ses dérivés en pédiatrie.) JACCOTtET, M. (1964). Rev. méd. Suisse rom., 84, 14. 
Treatment of Rheumatoid Arthritis. (Tratamento da artrite reumatóide.) VerztMan, L., Rubinstein, J., LeIte, N., and MARIA DA Silveira, J. (1964). J. bras. Med., 8, 96 . 26 refs.

Office Management of Rheumatoid Arthritis. DAvison, S. (1964). N.Y.St.J. Med., 64, 876. 14 refs.

Salicylate Therapy by Phleboclysis in Acute Articular Rheumatism. (Terapia salicilica per fleboclisis del reumatismo articolare acuto.) BoNDI, G. C. (1964). Policlinico, Sez. prat., 71, 256. 3 figs, 11 refs.

Rectal Administration of Acetylsalicylic Acid in Rheumatoid Arthritis. EnnevaARA, K., and Laine, V. (1963). Acta rheum. scand., 9, 277. 1 fig., bibl.

Non-specific Anti-inflammatory Agents. Boland, E. W. (1964). Calif. med., 100, 145.3 figs, 5 refs.

Anti-allergic Activity of Detergent and Antirheumatic Agents. Mizushima, Y., and Kasukawa, R. (1964). Int. Arch. Allergy, 24, 100.5 refs.

Haematological Complication of Phenylbutazone Therapy. McCarthy, D. D., and Chalmers, T. M. (1964). Canad. med. Ass. J., 90, 1061. 1 fig., 60 refs.

Clinical and Metabolic Effects of Indomethacin in Rheumatic Diseases. (Effetti clinici e metabolici dell'Indomethacin nelle malattie reumatiche.) BALlaBIO, C. B., Cirla, E., Girardi, G., Caruso, I., and Colombo, B. (1963). Reumatismo, 15, 487.4 figs, 11 refs.

Retinal Damage in Chloroquine Therapy. Algvere, P., CARlberg, O., and Ericson, L. (1963). Acta ophthal. (Kbh.), 41, 469.4 figs, 11 refs.

Electro-oculographic and Electroretinographic Evaluation of Retinal Function in Subjects undergoing Chloroquine Treatment. ElENIUS, V., and MÄNTYJÄRVI, M. (1963). Acta ophthal. (Kbh.), 41, 488.4 figs, 20 refs.

Ocular Toxicity of Chloroquine. BeRnSTEIN, H. N. (1963). Sight-sav. Rev., 33, 200. 3 figs, 20 refs.

Efficacy of Chloroquine Therapy in Rheumatoid Arthritis. (Sull'efficacia della terapia clorochinica nell'artrite reumatoide.) BaSSI, M., MenCI, S., and D'Alonzo, D. (1964). Arch. E. Maragliano Pat. Clin., 20, 113. 11 refs.

Correction of Circulatory Disturbances and their Significance in the Treatment of Rheumatic Diseases. (Die Bekämpfung der Durchblutungsstörungen in ihrer Bedeutung für die Therapie rheumatischer Erkrankungen.) Von Skramlik, E. (1964). Dtsch. med. J., 15, 246. 6 refs.
Therapeutic Applications of Hepatocatalase. BARCELó, P., Sans Solá, L., and Puig-MuSet, P. (1963). A.I.R. Arch. interamer. Rheum. (Rio de J.), 6, 537. 6 figs, 46 refs.

Trial of Niamide (Nialamide) in Rheumatology. (Essai du Niamide en rhumatologie.) Vinel, P. (1964). Rhumatologie, 16, 77.7 refs.

External Therapy of Polyarthritis. (Zur externen Therapie des polyarthritischen Formenkreises.) MülLER, G. (1964). Dtsch. med.J., 15, 182.

Limits of Spa Treatment in Rheumatology. (Quelles sont les limites de la crénothérapie en rhumatologie?) Françon, F., and Françon, J. (1963). Brasil-méd., 77, 185.

Tissue Implantation Therapy in Chronic Arthritis. (La terapia di innesto tissulare nelle artrosi.) SANToLINI, B. M., and Isola, M. (1963). Inform. med. (Genova), 18, 11. 20 refs.

Treatment of Extra-articular Rheumatism. (Die Therapie des extraartikulären Rheumatismus.) FÄHNDRICH, W. H. (1964). Med. Welt (Stuttg.), No .20, 1115.

Improved Method for the Conservative Treatment of het Lumbago-Sciatica Syndrome. (Uber eine verbesserte konservative Behandlung des Lumbago-IschiasSyndroms.) JANSEN, C. (1964). Dtsch. med. J., 15, 271. 2 figs, 38 refs.

Hip Joint after Radiotherapy. (La hanche radiothérapique.) Sèze, S.DE., RYCKeWAERT, A., LeSQUeSNe, M., and FrenauX, B. (1963). Rev. Rhum., 30, 695. 8 figs.

What can be done for the Rheumatoid Deformed Hand? Vaughan-JaCkson, O. J. (1964). Postgrad. med. J., 40, 280. 7 figs, 14 refs.

Surgical Treatment of the Hand and Foot in Rheumatoid Arthritis. (La chirurgie de la main et du pied dans la polyarthrite rhumatoïde.) MichotTE, L. J. (1963). J. belge. Méd. phys. Rhum., 18, 307.

Non-surgical Orthopaedic Treatment in Rheumatic Diseases. (L'orthopédie non sanglante dans les maladies rhumatismales.) ORY, M., and Henrard, A. (1963). J. belge. Méd. phys. Rhum., 18, 269.

Rheumatic Disease Surgery. IsDALE, I. C., RIDINGS, K. W., and TAPSELl, P. W. (1964). N.Z. med. J., 63, 140. 2 figs, 9 refs. 
Surgery and Orthopaedics in the Treatment of Rheumatic Diseases. (La chirurgie et l'orthopédie dans le traitement des affections rhumatismales.) RUELLE, M. (1963). J. belge. Méd. phys. Rhum., 18, 284.

\section{Other General Subjects}

Symposium on the Aetiology and Pathogenesis of Systemic Rheumatic Diseases. Special Editor G. P. RodnAN (1963). J. chron. Dis., 16, 833. Bibl.

Recent investigations into rheumatic diseases are reviewed in this symposium.

D. Hamerman, J. Sandson, and M. Schubert deal generally with the biochemistry and physiology of synovium, synovial fluid, and articular cartilage, and the changes which occur in disease.

A. J. Bollett describes work over the past three decades which has unravelled many details of the structure and intermediary metabolism of the connective tissue polysaccharides, and discusses what is known of the metabolism of polysaccharides in relation to cartilage softening and erosion.

C. H. Pearson describes an experimental form of polyarthritis produced by the intradermal injection of Freund's adjuvant into rats and he presents evidence to suggest that this adjuvant-induced arthritis is caused by hypersensitivity. The nature of such a hypersensitivity reaction and its relation, if any, to human disease are not known.

C. L. Christian reviews the serum rheumatoid factorits clinical associations, physicochemical properties, heterogeneity, experimental production and pathogenicity.

L. E. Sherman describes the serological abnormalities and circulating antibodies found in systemic lupus erythematosus.

E. G. L. Bywaters and J. T. Scott discuss the natural history of vascular lesions in rheumatoid arthritis on the basis of their sequential observations upon 35 patients; the variable prognosis is emphasized.

K. J. Black and J. J. Bunim give an account of their intriguing study of patients with Sjögren's syndrome and speculate upon the implications of the circulating antibodies which are so common in this condition.

Finally, G. P. Rodnan gives an exhaustive review of recent observation and current theories on the aetiology and pathogenesis of scleroderma.

There is a good bibliography, the eight papers providing a total of 672 references.

J. T. Scott

Correlation between Rheumatic Diseases and Rh Blood Groups. Cohen, A. S., Boyd, W. C., Goldwasser, S., CathCart, E. S., and Heisler, M. (1963). Nature (Lond.), 200, 1215. 2 refs.

In this communication from the Universities of Boston and Harvard, the authors report blood-group findings in 99 patients with articular disease (31 with rheumatoid arthritis, 31 with rheumatoid spondylitis, fifteen with gout, nine with disseminated lupus erythematosus, six with familial Mediterranean fever, and seven with various other diseases). Results obtained from the different disease groups showed no significant heterogeneity, but when the data were pooled it was shown:

(a) That there is a significant correlation between rheumatic disease and the absence of $\mathrm{Rh}$ antigen D;

(b) That there is no such correlation between rheumatic disease and antigens $C$ or $E$, or with the ABO blood group system;

(c) That there seemed to te a correlation with the absence of antigen $\mathbf{N}$. T. M. Chalmers

Clinical Observations of Behçet's Disease. [Japanese with English summary.] Ujihara, H., Kogure, M., Kimura, M., and Takahashi, S. (1963). Acta Soc. ophthal. jap., 67, 861. 10 refs.

Repcrt of ten cases. The latex-agglutination test and Coomts direct test were always negative in contrast to other collagen diseases.

Y. Mitsui

Behçet's Disease. A Report of 28 Cases. Mamo, J. G., and Baghdassarian, A. (1964). Arch. Ophthal. (Chicago), 71, 4.4 figs, 46 refs.

The authors report 28 cases of Behçet's disease, all from the Middle East. There is no racial predilection, but males are more commonly affected than females, and the disease usually commences between the ages of 20 and 30 years. Clinically, the disease is characterized by exacerbations and remissions, four to five each year, and it usually ends in blindness. Neurological complications occur in a small percentage. Malaise, generalized weakness, and fever may occur in the early stages, with aphthous lesions of the mouth, genital lesions, and hypopyon iritis. Tonsillitis and muscular stiffness are fairly common, and joint pains often occur. Erythema nodosum may be found. Various factors such as worry and dietary indiscretions may precipitate attacks. Macular oedema, retinal haemorrhages, perivasculitis, and neoformation of the retinal capillaries are common. Periarteritis and endarteritis are sometimes present. It appears that the ocular manifestations of the disease start in the posterior segment. The skin is abnormally reactive. Multiple thrombophlebitis is common. Any part of the central nervous system may be affected and especially the brain-stem. The cause is unknown and various theories suggest that it may be due to infection, to allergic reactions, and to vascular causes. The disease may belong to the collagen group. There is no effective treatment.

\section{A. G. Cross}

Behçet's Disease. (Morbus Behçet.) BARTH, E., and Mundt, E. (1964). Med. Welt (Stuttg.), No. 14, 774. Bibl.

Evolution of Rheumatology with Reference to the Prevention, Treatment, and Classification of Rheumatic Diseases. (Evoluzione della reumatologia ai fini preventivi e curativi e classificazione delle malattie reumatiche.) Messini, M. (1963). Clin.ter., 27, 406.

Suggestions for a Classification of the Rheumatic Diseases. (Sugestões para uma clasificación dos reumatismos.) Nava, P. (1963). Brasil-méd., 77, 153. 9 figs, 49 refs. 
Classification and Nomenclature of the Rheumatic Diseases. (A proposito de la clasificación y nomenclatúra de las afecciónes reumáticas.) Tichy, H. (1964). Folia clin. int. (Barcelona), 14, 67.

Suggested Classification and Nomenclature of Articular Disease. (Projet de classification et de nomenclature des maladies articulaires.) VerhaEghe, A., LebeurRE, R., and ZYLBERBERG, G. (1964). Lille méd., 9, 315.

Some Non- or Slightly Deforming Joint Diseases of Unknown Aetiology. (Quelques arthropathies non ou peu déformantes d'étiologie inconnue.) VAN Caumenberge, H., Franchimont, P., Lisin, N., and Salmon, J. (1964). Rev. méd. Liège, 19, 317.

"Diagnostic Criteria" in the Rheumatic Diseases. (Los "criterios diagnósticos" en las enfermedades reumáticas.) BARCEló, H. (1963). Arch. argent. Reum., 27, 70 . 7 refs.

"Diagnostic Criteria" of the International Committee for the Organization of Medical Sciences. (I "criteri diagnostici" del Comitato Internazionale per l'Organizzazione delle Scienze Mediche). MARrazzI, G., and VIARA, M. (1963). Reumatismo, 15, 445.

Bibliography of the History of Rheumatic Diseases, 19401962. Rodnan, G. P., and Eakin, L. (1964). Arthr. and Rheum., 7, 75.104 refs.

Rheumatism in the Province of Granada (a Medico-Social Study). (El reumatismo en la provincia de Granada.) IbaÑez, R., Salvattierra, D., and Gallego, J. (1964). Rev. Sanid. Hig. públ. (Madr.), 38, 58. 4 figs, 10 refs.

Socio-Medical Problems of Chronic Rheumatism. (Die sozialmedizinischen Problemen des chronischen Rheumatismus.) PopPer, L. (1964). Mitt. öst. Sanit.Verwalt., (15, 133.

Rheumatic Disease as a Cause of Incapacity for Work. (Incidenza della malattia reumática sulla incapácita lavorativa.) Selmi, G., and RASPADORI, F. (1964). Policlinico, Sez. prat., 71, 381. 16 refs.

Social Evaluation of Rheumatic Joint Disease, its Prophylaxis and Treatment. (Valore sociale della reumaartropatie e di una razionale loro prevenzione e terapia.) Chiarotti, C. (1963). Clin. ter., 27, 399.

Rheumatic Disease and Athletics. (Malattie reumátiche e medicina dello sport.) Venerando, A. (1963). Clin. ter., 27, 591.

Neurogenic Aspects of Rheumatic Disease. KELLY, M. (1963). A.I.R. Arch. interamer. Rheum. (Rio de J.), 6, 560 . 247 refs.
Psychogenic Syndrome. Psychogenic rheumatism of the Locomotor System. (El sindrome psicogeno del aparato locomotor. Reumatismo psicogeno.) Rotés-Querol, J. (1963). An. méd.-quir. Cruz Roja esp., 5, 497.

Felty's Syndrome and Generalized Aspergillosis. (1964). Marquette med. Rev., 30, 33.2 figs.

Sjögren's Syndrome. (Sindrome do Sjögren.) Verztman, L., Rubinstein, J., de PaOla, D., and Fernandes, R. (1964). J. bras. Med., 8, 69.5 figs, 38 refs.

Serum Sickness, Rheumatoid Arthritis, Ankylosing Spondylitis, and Related Syndromes. (La maladie sérique, la polyarthrite chronique évolutive, la spondylarthrite ankylosante, et les syndromes apparentés.) VAN Caunenberge, H., Franchimont, P., LfFebvre, P., and Lisin, N. (1964). Rev. méd. Liège, 19, 249.4 figs.

Relationship between Degenerative Rheumatism and the Rickettsias and Pararickettsias. (La relation entre le rhumatisme dégénératif et les rickettsies et les pararickettsies.) StoiA, I., and Dumitru, M. (1964). Rhumatologie, 16, 17.24 refs.

Paraneoplastic Paraproteinoses. (Paraprotéinoses paranéoplasiques.) Coste, F., Delbarre, F., Cayla, J., and Lisfranc, S. (1963). Bull. Soc. méd. Hôp. Paris, 114, 1169 . 5 figs.

Paraneoplastic Rheumatism? (Rhumatismes paranéoplasiques?) Coste, F., Delbarre, F., Cayla, J., Massias, P., and Weissenbach, R. (1963). Bull. Soc. méd. Hôp. Paris, 114, 1179. Bibl.

Bacterial Allergy in Rheumatology. (Alergia bacteriana en reumatológia.) Aguinaga, F. R., Villanueva, A. R., Perea, J. G., Barcenilla, R., Blas Made, A., and Elias, J. (1963). Brasil-méd., 77, 109.

Aetiology of Uveitis with Regard to Rheumatic Conditions. SVEC, V., and VYKYDAL, M. (1964). Rheumatism, 20, 17. 17 refs.

Eye in Rheumatic Joint Disease. (Occhio e reumaartropatie.) BIETTI, G. B. (1963). Clin. ter., 27, 446.

From Rheumatism to the Collagen Diseases. (Du rhumatisme aux maladies du collagène.) FornARA, $P$. (1964). Pédiatrie, 19, 9.3 figs.

Direct and Remote Effects of Cold in Rheumatology. (Azione diretta e disponente della perfrigerazione in reumatológia.) MACCo, G. Di. (1963). Clin.ter., 27, 442.

Arthrosis Syndrome. (El sindrome artrosico.) Urfbarri, G. (1963). An. méd.-quir. Cruz Roja esp., 5, 483 . 1 ref.

A Case of "Parkinsonian Rheumatism". (A propos d'un cas de "rhumatisme parkinsonien".) LEBEURRE, R., ZYLBeRBERG, G., and LeSAGE, R. (1964). Lille méd., 9, 366.2 figs. 